\title{
Electrolysis: Information and Opportunities for Electric Power Utilities
}

\section{Technical Report} NREL/TP-581-40605

September 2006

B. Kroposki, J. Levene, and K. Harrison National Renewable Energy Laboratory Golden, Colorado

P.K. Sen

Colorado School of Mines

Golden, Colorado

F. Novachek

Xcel Energy

Denver, Colorado

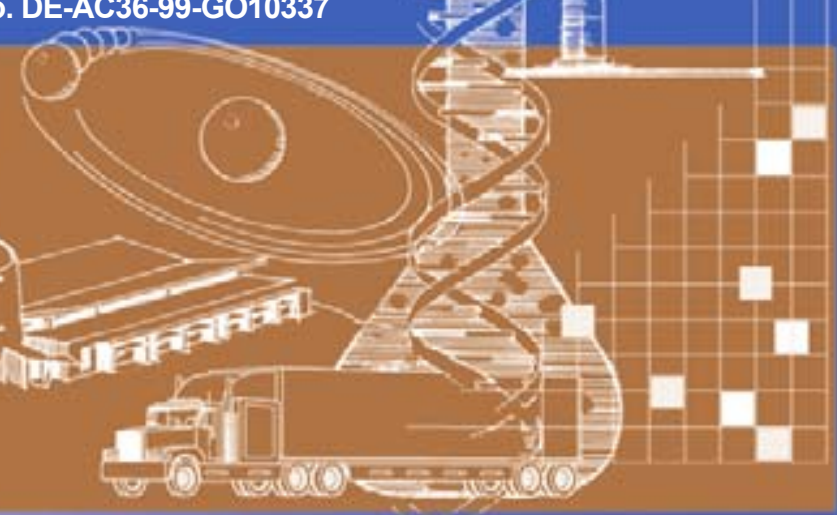


Electrolysis:

Information and Opportunities for Electric Power Utilities

B. Kroposki, J. Levene, and K. Harrison

National Renewable Energy Laboratory

Golden, Colorado

P.K. Sen

Colorado School of Mines

Golden, Colorado

F. Novachek

Xcel Energy

Denver, Colorado

Prepared under Task No. HY61.3620
Technical Report NREL/TP-581-40605

September 2006

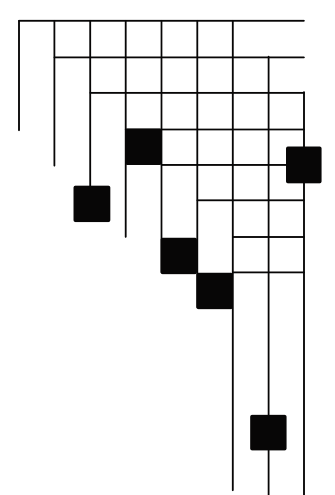

National Renewable Energy Laboratory

1617 Cole Boulevard, Golden, Colorado 80401-3393

303-275-3000 • www.nrel.gov

Operated for the U.S. Department of Energy

Office of Energy Efficiency and Renewable Energy

by Midwest Research Institute • Battelle

Contract No. DE-AC36-99-G010337 


\section{NOTICE}

This report was prepared as an account of work sponsored by an agency of the United States government. Neither the United States government nor any agency thereof, nor any of their employees, makes any warranty, express or implied, or assumes any legal liability or responsibility for the accuracy, completeness, or usefulness of any information, apparatus, product, or process disclosed, or represents that its use would not infringe privately owned rights. Reference herein to any specific commercial product, process, or service by trade name, trademark, manufacturer, or otherwise does not necessarily constitute or imply its endorsement, recommendation, or favoring by the United States government or any agency thereof. The views and opinions of authors expressed herein do not necessarily state or reflect those of the United States government or any agency thereof.

Available electronically at http://www.osti.gov/bridge

Available for a processing fee to U.S. Department of Energy and its contractors, in paper, from:

U.S. Department of Energy

Office of Scientific and Technical Information

P.O. Box 62

Oak Ridge, TN 37831-0062

phone: 865.576 .8401

fax: 865.576 .5728

email: mailto:reports@adonis.osti.gov

Available for sale to the public, in paper, from:

U.S. Department of Commerce

National Technical Information Service

5285 Port Royal Road

Springfield, VA 22161

phone: 800.553.6847

fax: 703.605.6900

email: orders@ntis.fedworld.gov

online ordering: http://www.ntis.gov/ordering.htm 


\section{Contents}

$\begin{array}{llr} & \text { Executive Summary } & \text { iv } \\ \text { I. } & \text { Introduction } & 1 \\ \text { II. } & \text { The Hydrogen Economy } & 4 \\ \text { III. } & \text { Hydrogen Production } & 5 \\ \text { IV. } & \text { Potential from Renewable Energy Sources_-Wind and Solar } & 9 \\ \text { V. } & \text { Economics of Electrolysis } & 12 \\ \text { VI. } & \text { Opportunities for Electrolysis } & 20 \\ \text { VII. } & \text { Future Directions } & 22 \\ \text { VIII. } & \text { Conclusions } & 24 \\ \text { IX. } & \text { References } & 25\end{array}$

\section{Figures}

Figure 1 Overview of petroleum imported and consumed in the United States

Figure 3

Hydrogen production pathway

Figure 4

Picture of the unipolar (tank) design

Figure 5

Picture of the bipolar (filter-press) design

Figure 6

$\mathrm{PV}$ and wind electrolysis configurations

Figure 7

Hydrogen potential from solar and wind resources

Figure 8

Components of the cost of hydrogen

Figure 9

Cost of hydrogen versus electricity without equipment costs

Figure 10

Cost of solar technologies (2005-2015)

Figure 11

COE baseline and targets for low wind speed technology (LWST)

Figure 12

Percent of land area in the continuous United States estimated to

have a Class 4 or higher wind power

Figure 13 Current (2005) wind hydrogen production system: capacity factor and electricity price effects on hydrogen cost in $\$ / \mathrm{kg}$

Figure 14 Future wind hydrogen production system: capacity factor and electricity price effects on hydrogen cost in \$kg

Figure 15 Examples of wind electrolysis being produced centrally or distributed at the point of use

Figure 16 Xcel-NREL Wind2H2 project diagram 


\section{Executive Summary}

Recent advancements in hydrogen technologies and renewable energy applications show promise for economical near- to mid-term conversion to a hydrogen-based economy. As the use of hydrogen for the electric utility and transportation sectors of the U.S. economy unfolds, electric power utilities need to understand the potential benefits and impacts. This report provides a historical perspective of hydrogen, discusses the process of electrolysis for hydrogen production (especially from solar and wind technologies), and describes the opportunities for electric power utilities. 


\section{Introduction}

Because of the effects of carbon emissions into the atmosphere on global climate change, a carbon-constrained world is coming and alternative energy sources will be required to supplement the carbon-intensive sources that currently power homes, businesses, and motor vehicles. Natural gas is available, but the supply is limited and its cost will rise because of increased demand. Coal will continue to supply power for most of our electricity demand, but technologies to enable carbon sequestration are in their infancy. Advanced nuclear energy can be used to produce electricity, but issues that surround nuclear waste disposal prevail and no new nuclear plants have been built in the United States in the last 30 years.

One promising solution to this problem is the direct use of hydrogen. Hydrogen, the lightest element, is not a primary energy source like oil or coal, but instead is an energy carrier like electricity. Hydrogen can be manufactured or extracted from hydrogen-rich materials such as coal, natural gas, biomass, or water. Currently, the primary means of manufacturing hydrogen is to strip it from natural gas (mostly methane) via steam methane reforming (SMR). However, the technologies to produce hydrogen from nonfossil sources such as biomass, wind, and solar are also available. Benefits of hydrogen production from nonfossil sources include the fact that the hydrogen production and combustion cycle can produce less greenhouse gases than competing fossil pathways and that, unlike electricity, hydrogen can be stored quite easily.

Utility companies are uniquely positioned to play a major role if hydrogen is to become a major energy carrier. As the United States moves toward a secure energy future, its domestic resources can provide clean energy for various energy sectors. In the near term, utilities can begin to consider the current hydrogen market as a first step to building a new energy infrastructure: the United States consumed 84.3 billion $\mathrm{m}^{3}$ ( 7.6 billion $\mathrm{kg}$ ) of hydrogen in 2003 [1]. Eventually, utilities can either become hydrogen fuel producers or can supply electricity to hydrogen fuel producers who provide the energy needed to fuel vehicles.

The current market for hydrogen is divided into two segments: captive users, who produce the hydrogen at the location where it is to be used, and merchant users, who have their hydrogen delivered to the point of use. In the United States and worldwide, the captive market is the larger, and includes chemical producers (such as ammonia, methanol, hydrogen peroxide, and pharmaceuticals), refineries, fat and oil hydrogenation, and metal production. The smaller merchant market serves industries such as electronics manufacturers, float gas producers, and public utilities for generator cooling in nuclear plants [1].

The future market for hydrogen is much larger. If hydrogen is to be used as a transportation fuel, the United States could conceivably replace the 9.1 million barrels per day (bbl/d) (140 billion gal/yr) of gasoline consumed in 2004 with domestically produced hydrogen (Figure 1). The energy equivalent of this much gasoline is $17.3 \times 10^{15} \mathrm{Btu}$, assuming approximately 5.2 million Btu/bbl of motor gasoline [2]. 
Figure 1 depicts the amount of petroleum that is consumed in the United States in millions of barrels per day from 1950 to 2004 [2]. The current rate of petroleum use is worrisome, since the U.S. production of petroleum has been in steady decline since the 1970s. Our use of foreign sources of petroleum has increased to the point where we now import $63 \%$ (12.9 million bbl/d) of our total use [2].

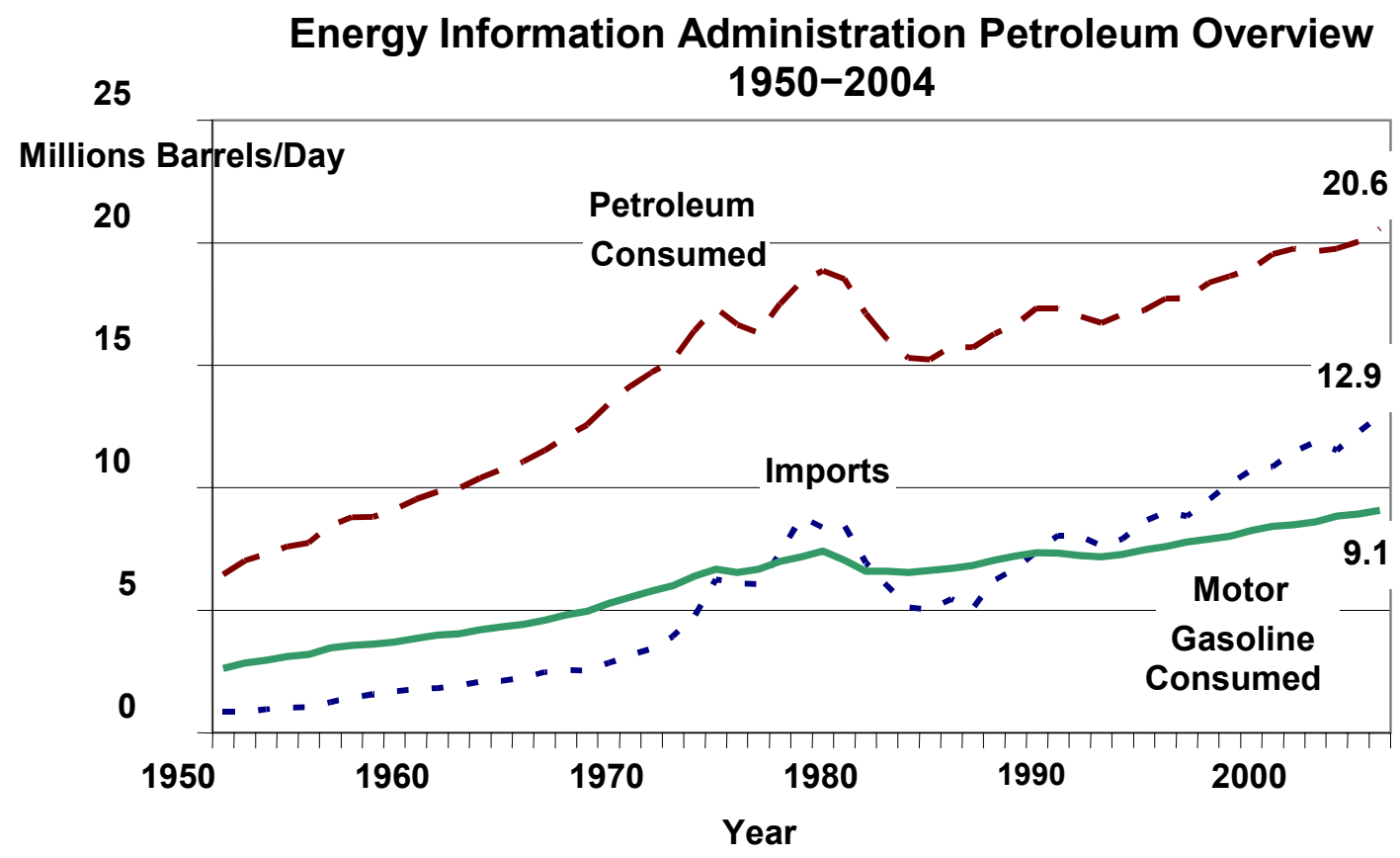

Figure 1. Overview of petroleum imported and consumed in the United States

Figure 2 shows how the energy in motor gasoline consumed compares to the current U.S. electricity generation capacity.

In 2004, $17.3 \times 10^{15}$ Btu of gasoline were consumed (Figure 2), and $12.9 \times 10^{15}$ Btu $(3,717$ $\mathrm{TWh}$ ) of electricity were generated by the electric power sector [2]. Thus, the potential to participate in the transportation market could lead to significant new opportunities for utilities. 


\section{EIA Electric Power Net Electricity Generation and U.S. Motor Gasoline Consumption}

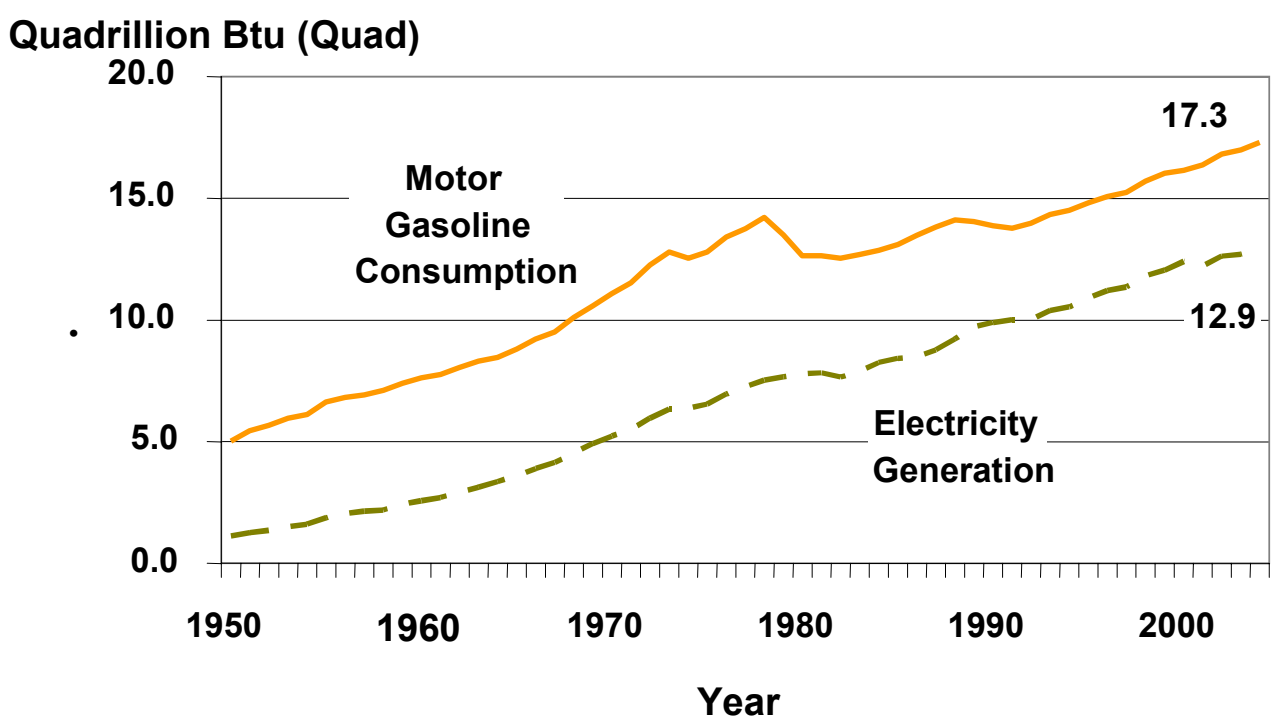

Figure 2. 2004 Energy consumption by sector 


\section{The Hydrogen Economy}

The major advantages of using hydrogen to supply energy include:

- Hydrogen can be produced from a clean energy sources.

- Hydrogen can be distributed and stored in a variety of ways.

- Hydrogen can replace fossil fuels to provide electricity and transportation fuels.

- Domestic resources can be used to produce the hydrogen and lead to energy independence

The idea of a society that can use hydrogen as an energy carrier is not new. One of the earliest concepts for a hydrogen-based economy was proposed in the writings of Jules Verne in 1874. In The Mysterious Island, a character remarks that "water will one day be employed as fuel, that hydrogen and oxygen of which it is constituted will be used, simultaneously or in isolation, to furnish an inexhaustible source of heat and light" [3, 4]. Between 1900 and 1960, progressive thinkers proposed many ways to produce and use hydrogen in numerous applications, but the price of fossil fuels typically was low enough to make these opportunities uneconomical. The oil embargo of 1973 forced the United States and other countries to reconsider alternatives to the fossil-fuel based economy. The term hydrogen economy was first introduced in the early 1970s [5-7] to describe the use of hydrogen to replace fossil fuels and as an alternative to the all-electric economy proposed by the nuclear industry.

The all-electric economy, proposed during the 1970s, with the advent of inexpensive nuclear electricity [5], has some significant drawbacks. Electricity storage is difficult and expensive. Pumped-storage hydro and compressed air use geographic land features and are therefore site specific. Today's battery technology cannot deliver economical utility-scale storage or meet the required cost and range targets for vehicular travel. Prototype all-electric vehicles like General Motors' EV1 did not provide the driving range (hundreds of miles) that people expect from a car. Another major issue in the transportation sector is that the charging time for vehicle applications can be as long as 4 hours depending on the state of charge, whereas liquid or gaseous fuel applications can have fueling times shorter than 5 minutes.

As electric utilities examined the combined potential benefits of the hydrogen economy and the all-electric economy, the term hydrogen-electric economy was also developed [8] to describe the possibilities of combining production, transmission, and sales of both energy carriers. This idea integrates production, storage, and use to maximize system efficiencies.

If hydrogen can be produced economically, hydrogen-based internal combustion engines (ICEs) and fuel cells could be used to provide electrical power in distributed energy applications. If the loads can also use the heat from the distributed generators, a combined heat and power (CHP) application can increase the overall efficiency of the packaged system. 


\section{Hydrogen Production}

Hydrogen can be produced from a variety of sources. Figure 3 shows the variety of hydrogen production pathways and highlights the methods that are supported by the electric utilities. The importance of these pathways for making fuel is that they can be produced domestically without relying on foreign sources.

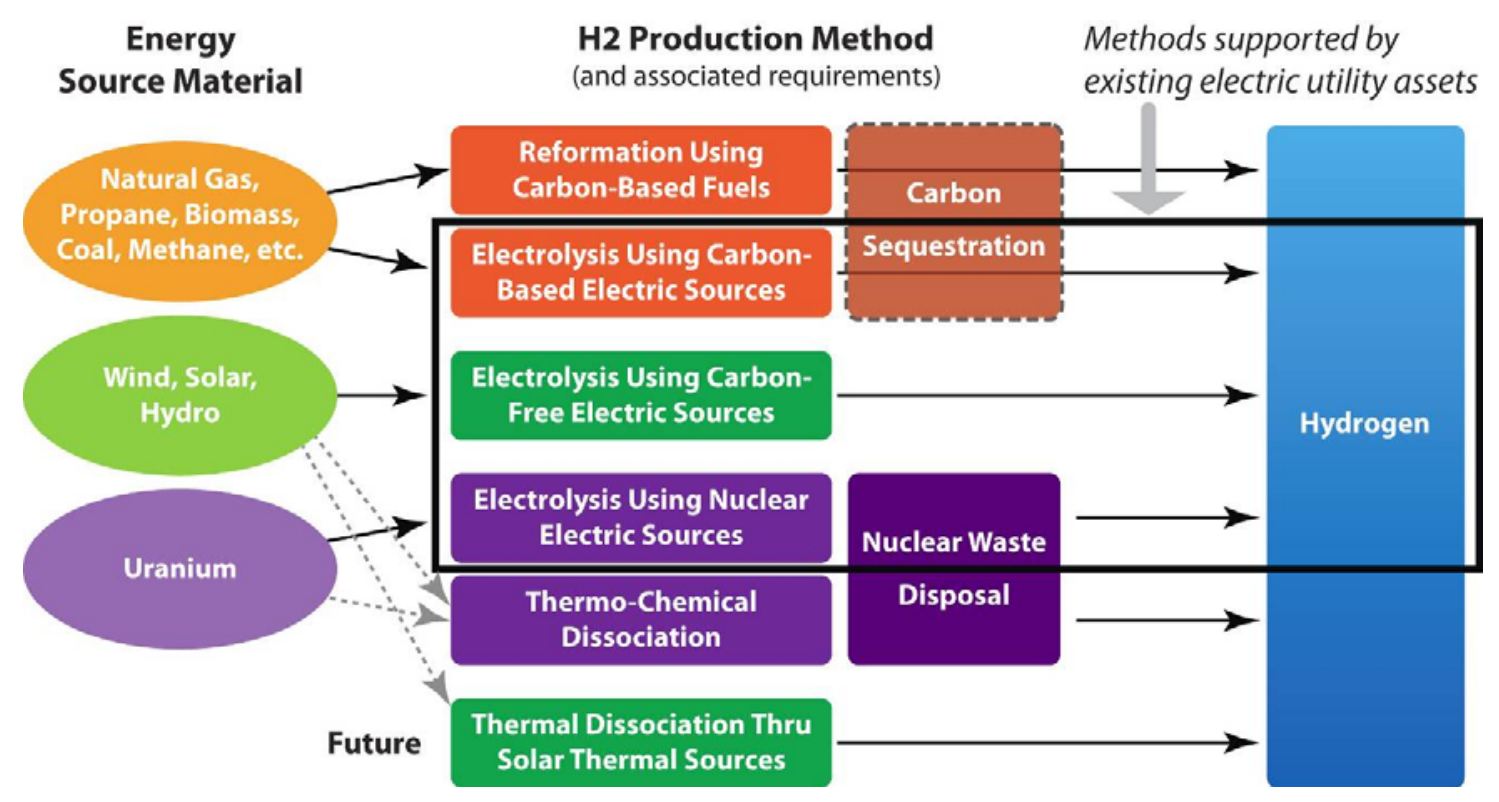

Figure 3. Hydrogen production pathway

Global hydrogen production stands at around 448 billion $\mathrm{m}^{3} / \mathrm{yr}$ (40 billion $\mathrm{kg} / \mathrm{yr}$ ) [1]. Currently, the main methods of producing hydrogen are by reforming natural gas and dissociating hydrocarbons. A smaller amount is produced by electrolysis [1]. Reforming natural gas is cost effective and accounts for roughly $48 \%$ of the hydrogen currently produced worldwide [9]. In this process steam is used to split hydrogen from natural gas.

SMR is currently the least expensive way to produce large quantities of hydrogen $(\$ 1.00-$ $\$ 5.00 / \mathrm{kg}$ of hydrogen). A major drawback to using SMR is that the process is based on a nonrenewable fossil-fuel source. The feedstock price is volatile, and natural gas is primarily a nondomestic resource-liquefied natural gas (LNG) is already imported into the United States. The reactions of the SMR process also produce carbon dioxide (which is a risk if the world moves to a carbon-constrained global economy), and the hydrogen product gas can have high levels of impurities.

Electrolysis uses direct current (DC) electricity to split water into its basic elements of hydrogen and oxygen. Since this process uses only water as a source, it can produce up to 99.9995\% pure hydrogen and oxygen. Electrolysis was discovered in 1800 by William 
Nicholson and Sir Anthony Carlisle shortly after Alessandro Volta invented the electric battery. The electrolyzer industry grew substantially during the 1920s and 1930s. This included products from companies such as Oerlikon, Norsk Hydro, and Cominco in multimegawatt sizes [10-12]. Most of these installations were near hydroelectric plants that supplied an inexpensive source of electricity. As more hydrogen was needed for industries, SMR gradually took over as the hydrogen production process of choice because it was less expensive.

Electrolyzers are still used in places where low electricity prices are available or that have high hydrogen purity requirements. As the price of natural gas increases, electrolysis becomes a viable option for competition in the hydrogen market, and electric utilities are well placed to provide the electricity for electrolysis for producing the hydrogen. In the future hydrogen economy, an added benefit of electrolytic hydrogen production is that since the electric power industry is almost entirely supported by U.S. energy resources, it offers a more stable and secure energy future than oil or imported LNG.

Ideally, $39 \mathrm{kWh}$ of electricity and 8.9 liters of water are required to produce $1 \mathrm{~kg}$ of hydrogen at $25^{\circ} \mathrm{C}$ and 1 atmosphere pressure. Typical commercial electrolyzer system efficiencies are $56 \%-73 \%$ and this corresponds to $70.1-53.4 \mathrm{kWh} / \mathrm{kg}$ [13]. Two basic types of lowtemperature electrolyzers - alkaline and proton exchange membrane - are currently being manufactured.

The first water electrolyzers used the tank design and an alkaline electrolyte [11]. These electrolyzers can be configured as unipolar (tank) or bipolar (filter press) designs. In the unipolar design (Figure 4), electrodes, anodes, and cathodes are alternatively suspended in a tank that is filled with a $20 \%-30 \%$ solution of electrolyte (potassium hydroxide in pure water). In this design, each cell is connected in parallel and operated at $1.9-2.5 \mathrm{~V}_{\mathrm{dc}}$.

The advantage to this design is that it is extremely simple to manufacture and repair. The disadvantage is that it usually operates at lower current densities and lower temperatures [11]. More recent unipolar designs include operation at high hydrogen pressure outputs (up to $6,000 \mathrm{psig})$.

The bipolar design (Figure 5), often called the filter-press, has alternating layers of electrodes and separation diaphragms that are clamped together. The cells are connected in series and result in higher stack voltages. Since the cells are relatively thin, the overall stack can be considerably smaller than the unipolar design. The advantages to the bipolar design are the reduced stack footprints, higher current densities, and its ability to produce higher pressure gas. The disadvantage is that it cannot be repaired without servicing the entire stack [11, 14]. Fortunately, it rarely needs servicing. Previously asbestos was used as a separation diaphragm, but manufacturers have replaced or are planning to replace this with new polymer materials such as Ryton ${ }^{\circledR}$ [15]. 


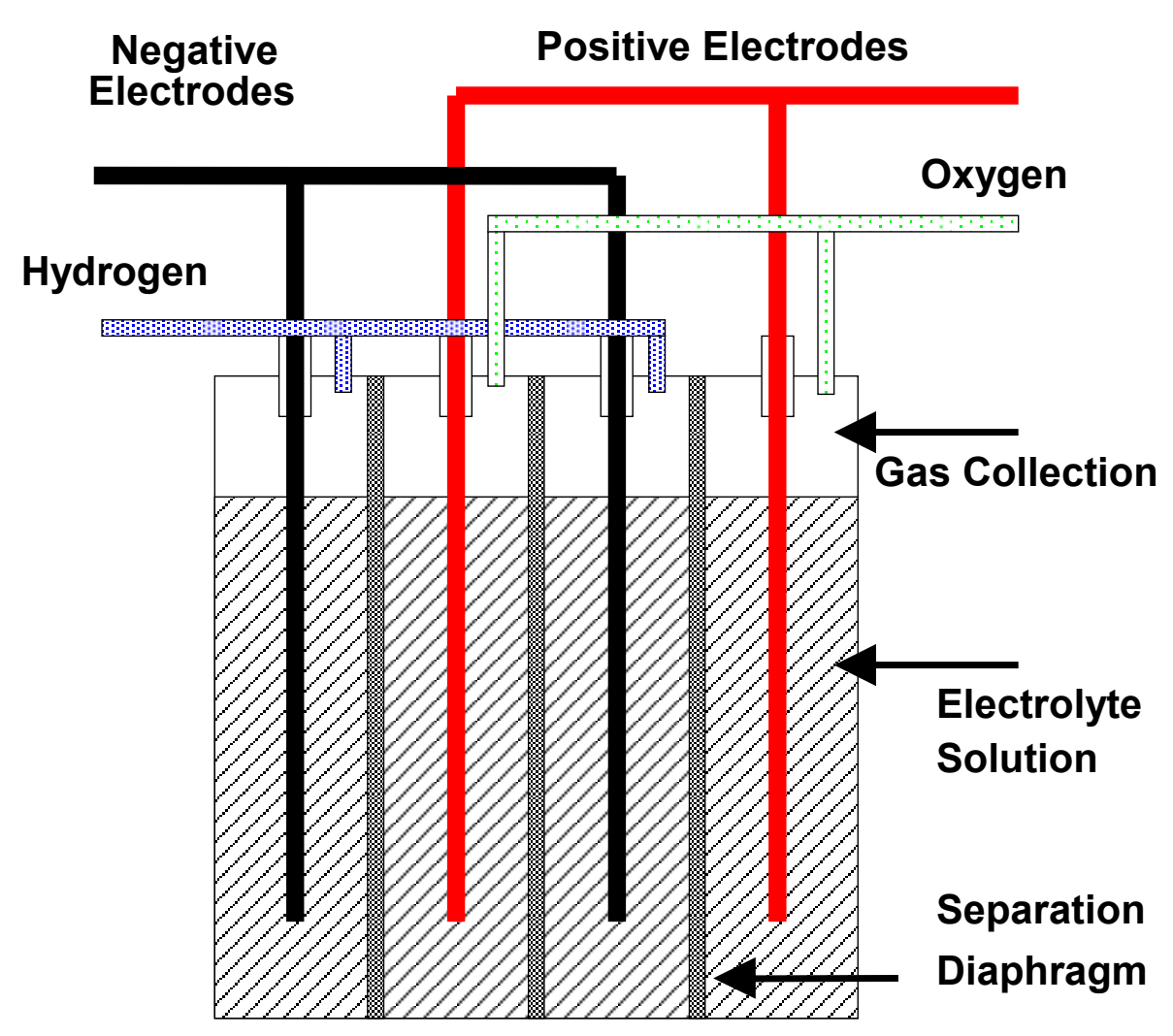

Figure 4. Picture of the unipolar (tank) design

A second commercially available electrolyzer technology is the solid polymer electrolyte membrane (PEM). It was originally developed as part of the Gemini space program [11]. In a PEM electrolyzer, the electrolyte is contained in a thin, solid ion-conducting membrane rather than the aqueous solution in the alkaline electrolyzers. This allows the H+ ion (i.e., proton) to transfer from the anode side of the membrane to the cathode side, and separates the hydrogen and oxygen gases. Oxygen is produced at the anode side and hydrogen is produced on the cathode side. The most commonly used membrane material is Nafion ${ }^{\circledR}$ from DuPont. PEM electrolyzers use the bipolar design and can be made to operate at a high differential pressure across the membrane.

Several factors influence the performance of electrolyzers. These usually involve tradeoffs between the operating voltage, rate of hydrogen production, and capital costs. The optimization for these parameters is unique to each manufacturer.

Increasing temperature reduces the stack operating voltage of the electrolyzer because the amount of energy needed to initiate the reaction (activation) is reduced. In other words, the reactions at the electrodes are increased, which lowers the overpotential (loss) at the electrode. In addition, the theoretical reversible potential of the electrolyzer cells is reduced. 
This means that an overall increase in efficiency can be realized by operating at higher temperatures, but this can increase corrosion rates of electrodes and separator membranes [11]. Increased temperatures can also require that other materials be used in the balance of plant.

There are also advantages to operating the electrolyzers at higher pressures. These include reductions in specific power consumption, a reduced need for gas compressors, and smaller electrolysis cells $[3,16]$.

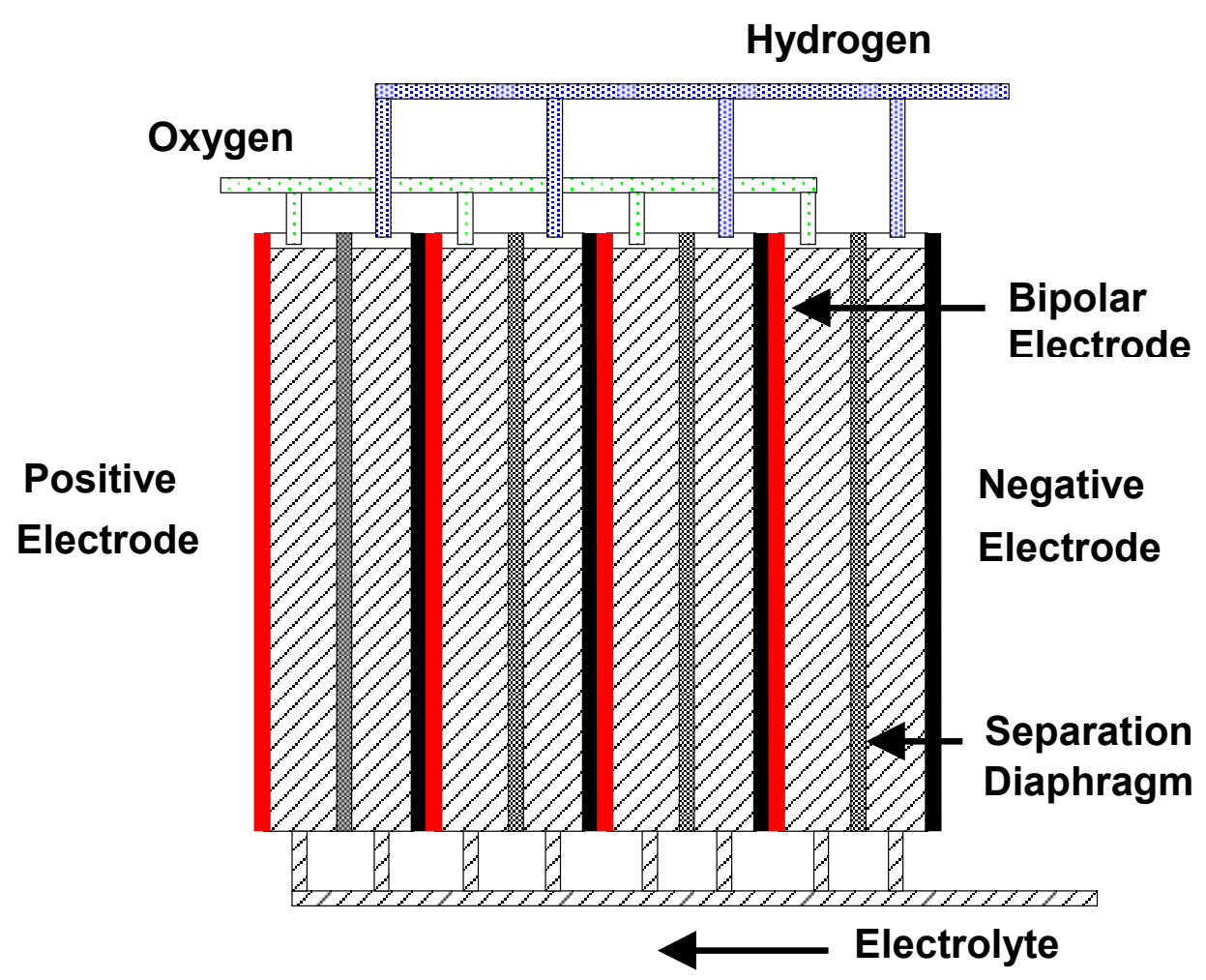

Figure 5. Picture of the bipolar (filter-press) design 


\section{Potential from Renewable Energy Sources- Wind and Solar}

The idea of using renewable energy to produce electricity for electrolysis was born in the early 1900s. In 1923, John B.S. Haldane proposed that hydrogen and oxygen could be produced via electrolysis from electricity generated by wind turbines. The hydrogen and oxygen could then be stored and later used to make electricity via ICEs or fuel cells when electric power is needed or for industrial, transportation, or heating applications [17].

In the 1930s, Hermann Honnef conceptualized the use of megawatt-scale wind turbines to produce electricity for hydrogen production [18]. Other ideas to use wind turbine technology for hydrogen production were proposed in the early 1970s. William Heronemus anticipated the increases in wind turbine sizes. He proposed using megawatt-scale offshore wind turbines to electrolyze seawater. The hydrogen produced would then be piped back to land. Smaller scale wind electrolysis systems that focused on residential applications were also proposed by L.W. Zelbey [18].

With the advent of new solar technologies in the 1960s and 1970s, electrolysis via solar energy was proposed and studied by numerous people [19-21]. Since that time a few experiments have detailed the use of solar energy and photovoltaic (PV) systems for electrolytic production of hydrogen $[22,23]$. There has also been a great deal of research about using wind to produce electricity for electrolysis [24-28]. These papers discuss wind electrolysis and include techniques for optimization of electrolyzer efficiency by switching stack components and integration with power electronics.

Figure 6(a-e) shows several ways to use renewable energy (electricity) from PV and wind energy for hydrogen production. Figure 6(a) shows the direct conversion of water to hydrogen and oxygen via a direct photoelectrochemical (PEC) approach. This method may offer the most direct and efficient way to produce hydrogen from water, but it is still in the research stages. Figure 6(b) uses PV to produce DC electricity and to connect directly to an electrolyzer stack. Figure 6(c) shows how PV could supply energy to the grid, which is then used to produce hydrogen via electrolysis. This approach allows for the solar electricity production to be located separately from hydrogen production. The two wind hydrogen pathways shown in Figure 6(d) and Figure 6(e) demonstrate electricity produced at the wind site, and transferred to the hydrogen generation point via the grid; and wind used to coproduce hydrogen and grid electricity at the wind site. Figure 6(d) the rectifier to produce DC electricity for the electrolyzer stack is located at the electrolyzer. In Figure 6(e) DC electricity current is taken from a rectifier inside the wind turbine and directly connected to an electrolyzer.

A recent study [29] examined the potential for hydrogen production from renewable resources, including solar and wind. Figure 7 shows the potential for hydrogen production from wind and solar. This study shows that the United States has ample solar and wind resources to meet its transportation fuel needs, and shows where those resources are most 
prevalent. However, renewable energy systems face challenges to reduce the cost of electricity and to independently meet the energy requirements of distributed fueling stations.
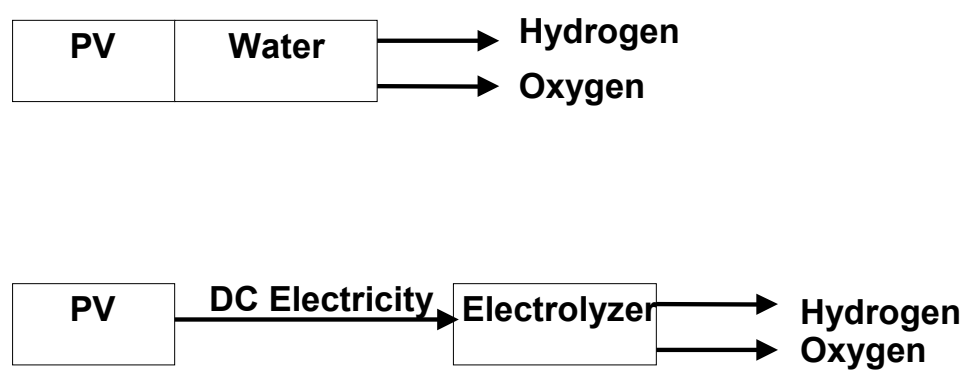

(b) Direct PV to Electrolysis
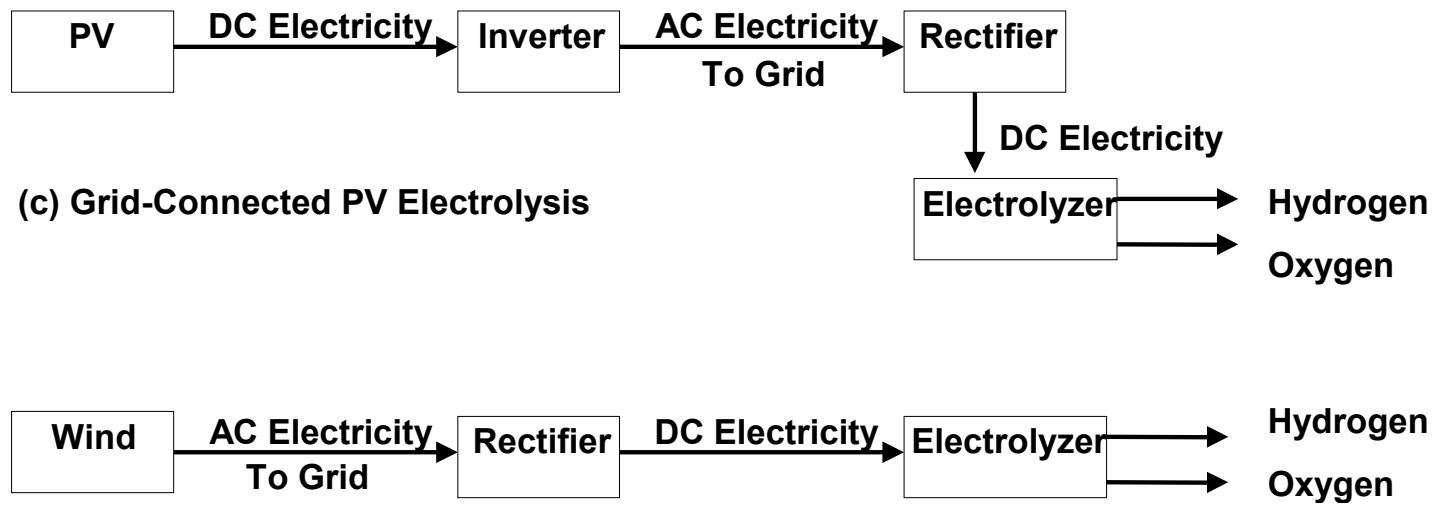

(d)

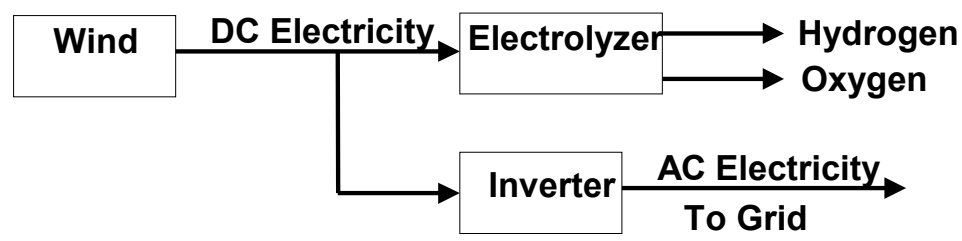

(e) Direct Wind DC to Electrolysis with Optional Grid Connection

Figure 6. PV and wind electrolysis configurations

In the past, the greatest drawbacks to using wind and solar technologies were the prohibitive capital costs of the technologies and the variable nature of the resources. Over the last 30 years, the costs of solar and wind have significantly declined. Section V summarizes the economics of electrolysis from a variety of production methods, including renewables. 


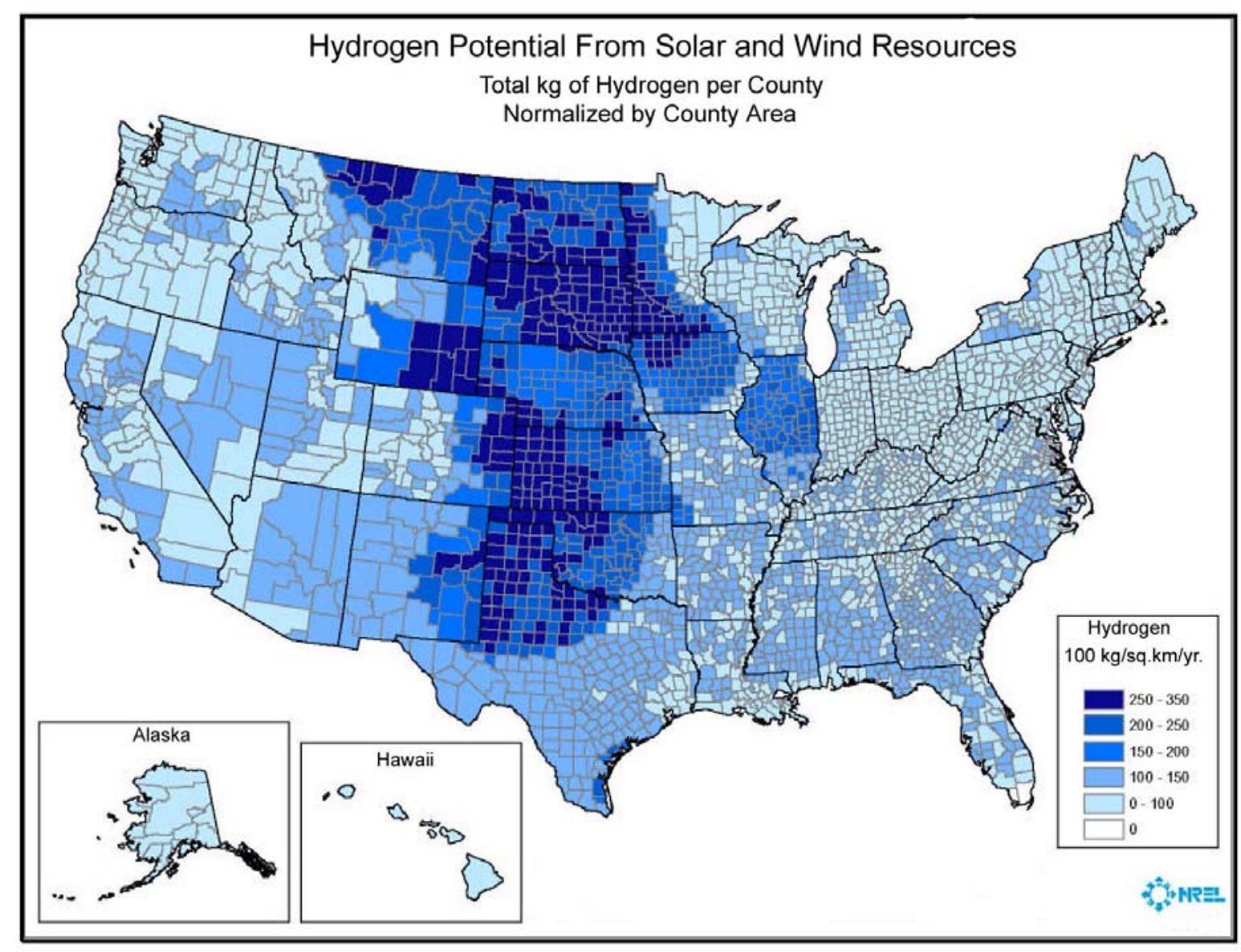

Figure 7. Hydrogen potential from solar and wind resources 


\section{Economics of Electrolysis}

Figure 8 shows the cost of producing hydrogen from a large-scale electrolysis system that is available today and uses either industrial or commercial electricity rates [29]. This analysis was conducted with the Hydrogen Analysis (H2A) tool, which was developed to allow analysts to use a consistent approach, a standard methodology, and transparent assumptions to provide hydrogen production costs [30].

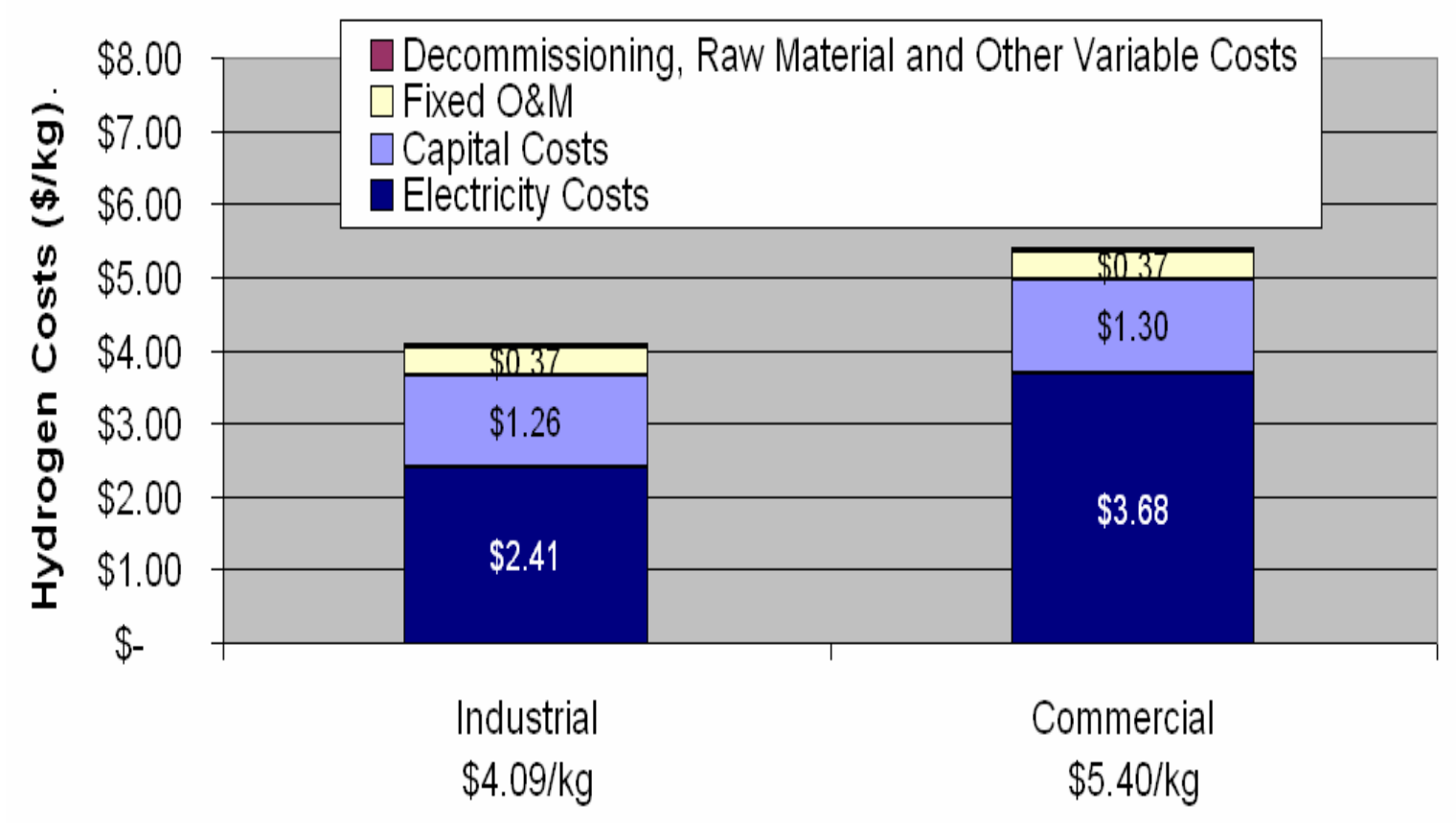

\section{Hydrogen Price for Forecourt Sized Electrolyzer ( $1000 \mathrm{~kg} /$ day)}

Figure 8. Components of the cost of hydrogen

$\mathrm{H} 2 \mathrm{~A}$ uses $\$ / \mathrm{kg}$ as the standard unit of hydrogen price because one kilogram of hydrogen has roughly the same energy content of a gallon of gasoline. If a kilogram of hydrogen and a gallon of gasoline have the same cost and are burned in engines with the same efficiency, the resultant $\$ /$ mile will be similar.

For this study, electricity prices were based on standard H2A projections from 2005 to 2045. Industrial rates were $\$ 0.044-\$ 0.050 / \mathrm{kWh}$, with a value of $\$ 0.045 / \mathrm{kWh}$ in 2005 . Commercial rates were $\$ 0.067-\$ 0.077 / \mathrm{kWh}$, with a value of $\$ 0.069 / \mathrm{kWh}$ in 2005 . The study shows that electricity costs are the most significant contributor to hydrogen costs produced via electrolysis, contributing $60 \%$ and $68 \%$ of the total cost when industrial and commercial electricity rates are used, respectively. The capital costs are the second highest cost contributor. 
The U.S. Department of Energy (DOE) has set the cost target for hydrogen at $\$ 2.00-\$ 3.00 / \mathrm{kg}$ to serve the transportation market [31]. The costs calculated in Figure 9 include production, not delivery. As a result, to meet this target, the cost of hydrogen produced via electrolysis from industrial electricity needs to be reduced by at least $\$ 1.00$, and likely more than $\$ 2.00$ (2005 dollars) to meet the DOE cost goals.

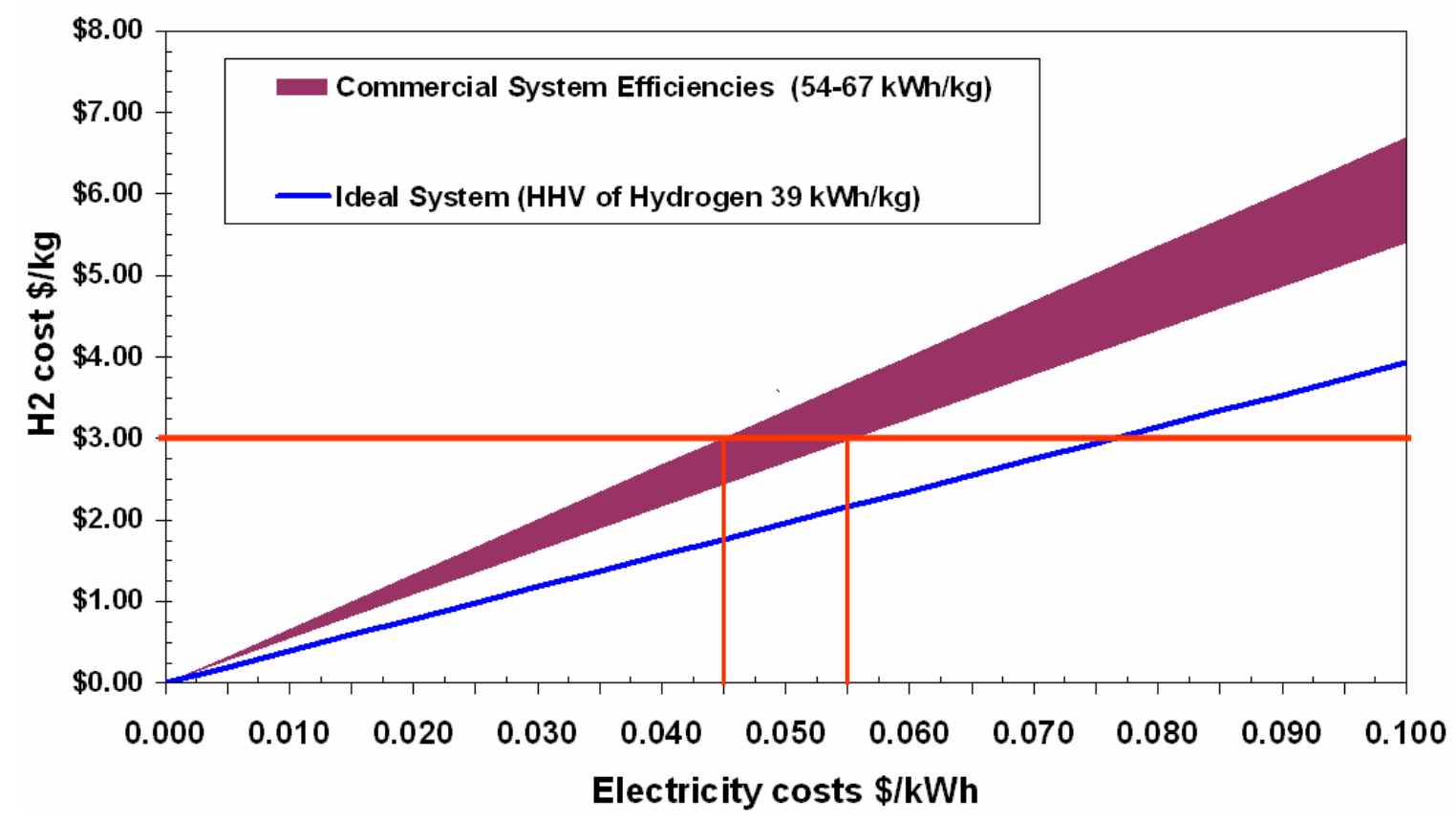

Figure 9. Cost of hydrogen versus electricity without equipment costs

There are opportunities for reducing the capital and operating costs of the electrolyzer, but electricity prices are a key driver to hydrogen cost. Figure 9 shows electricity versus hydrogen costs, but takes into account only the cost of the electricity used to split the water into hydrogen and oxygen. This figure represents a boundary analysis of the electrolysis technology. If the electrolyzer were free, had no operation and maintenance costs (other then electricity), operated at a 100\% capacity factor, and had no delivery or dispensing costs, this figure would show the cost at which hydrogen could be produced. The results demonstrate that to meet the DOE target of $\$ 3.00 / \mathrm{kg}$, electrolyzers with today's efficiencies would need to have access to electricity prices lower than $\$ 0.045-\$ 0.055 / \mathrm{kWh}$. Ideal systems would need to have access to electricity prices lower than $\$ 0.075 / \mathrm{kWh}$, which represents the highest possible electricity price that low-temperature electrolyzers would be able to use to produce hydrogen at $\$ 3.00 / \mathrm{kg}$. The importance of electricity price is a key reason why utilities need to be involved if the future hydrogen economy includes electrolysis.

One of the most promising ways to provide clean, domestic, carbon-free energy to electrolysis units is via electricity produced from wind and solar technologies. However, these technologies face challenges with electrolysis in the areas of cost and energy output variability. Both wind and solar sources produce electricity that varies with the natural 
processes that drive them. For a solar system, typical capacity factors are about $25 \%$; wind systems are around $35 \%$. These values vary across the United States based on the quality of the resource.

Solar technologies include PV, concentrating solar power (CSP), and solar water heating. These technologies have seen a dramatic price decline since the 1970s. Current costs and projections to 2015 are shown in Figure 10. This shows that solar technologies that convert their power to alternating current (AC) electricity will not to be able to meet the $\$ / \mathrm{kWh}$ levels needed to meet the DOE cost targets for hydrogen production before the 2015 range. But there may be ways to optimize a directly connected PV array to an electrolyzer that can meet the cost targets. Since the PV array produces DC electricity and the electrolyzer stack uses DC electricity the elimination of some power electronics could make a direct PV to electrolysis system economical.

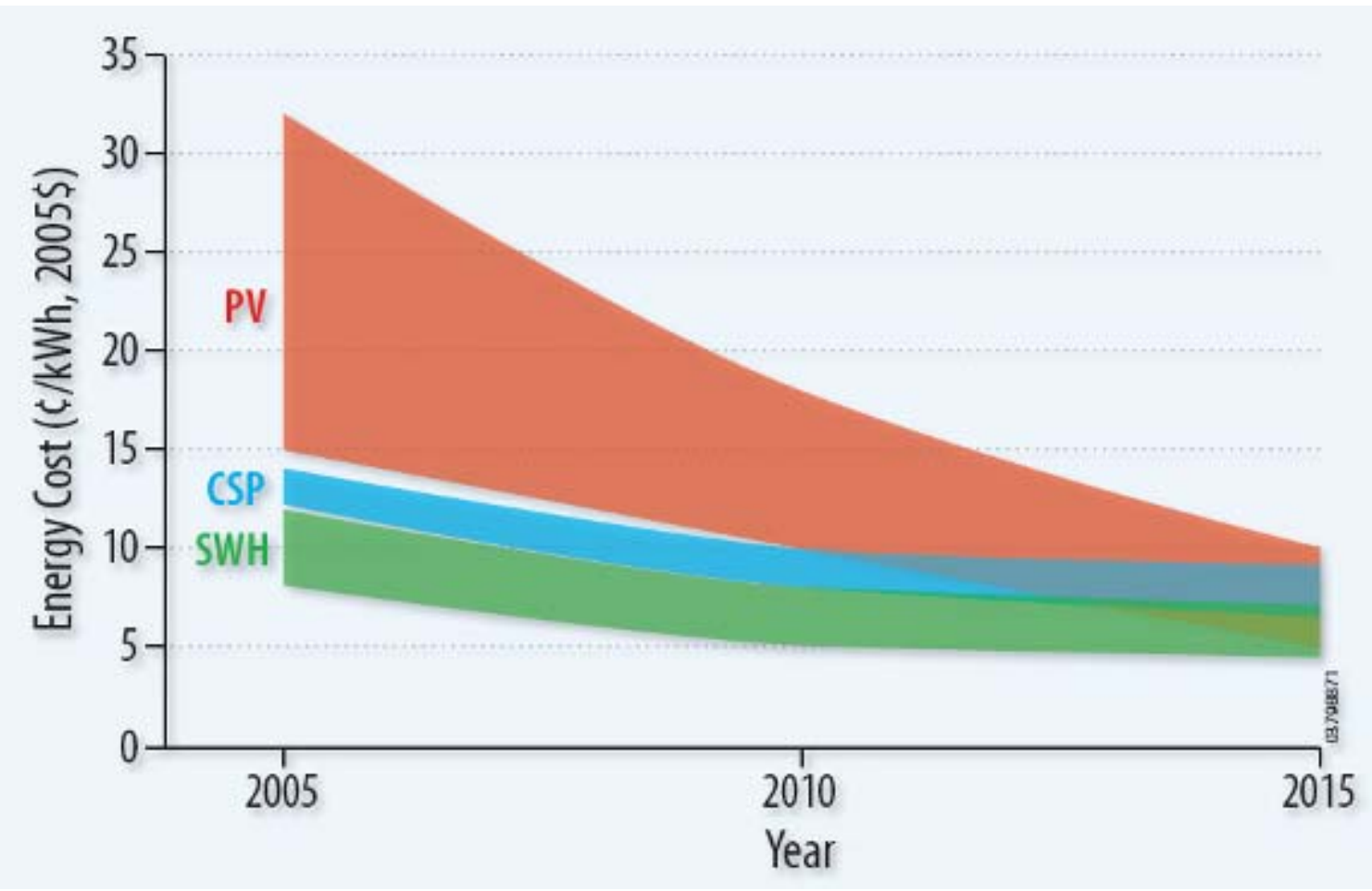

Figure 10. Cost of solar technologies (2005-2015) [32]

Wind turbine technologies have also seen a significant decline in the cost of energy (COE) since the $1970 \mathrm{~s}$. Wind turbines can currently produce electricity at $\$ 0.045-\$ 0.055 / \mathrm{kWh}$ in the Class 4 wind regions that are broadly available across the United States, depending on many factors, including project financial structure. Figure 11 shows the Low Wind Speed Technology cost targets (in cents) for wind technologies in Class 4 locations [33]. 


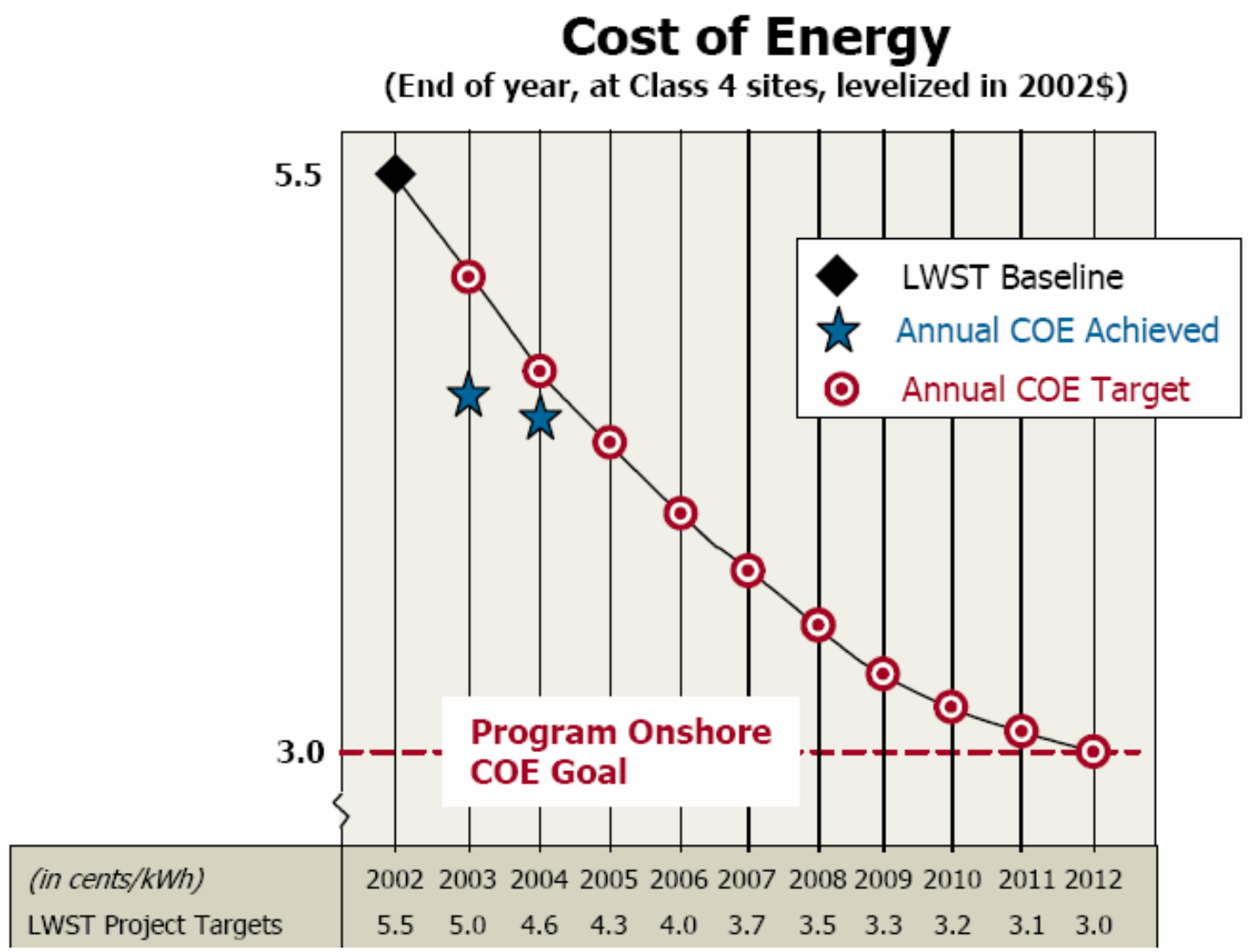

Figure 11. COE baseline and targets for low wind speed technology (LWST) 2002-2012

Figure 12 shows the areas of the country that have Class 4 wind locations. Most of the Class 4 and greater wind resources are in North Dakota, South Dakota, Minnesota, Wyoming, Iowa, Colorado, Kansas, and Texas. Since these sites are typically far from major population and load centers, transmission costs of the wind electricity or hydrogen must be considered.

For onshore Class 4 and higher land areas have an area of 568,944 $\mathrm{km}^{2}$ after standard exclusions (such as National Park Service areas, Fish and Wildlife Service areas, federal lands with special designations, Forest Service lands, and Department of Defense lands) are applied. Assuming $5 \mathrm{MW} / \mathrm{km}^{2}$ [34] installed nameplate capacity calculates to 2,845,000 MW of potential for Class 4 and higher locations. The amount of hydrogen that can be produced from this class for wind can be calculated by multiplying the amount of energy produced by the electrolyzer energy need. Using $58 \mathrm{kWh} / \mathrm{kg}$ for the electrolyzer energy need, which is a system electrolyzer efficiency of $67 \%$ this leads to a hydrogen production rate of 154 billion $\mathrm{kg} / \mathrm{yr}$ from Class 4 and higher wind in the United States. In 2004, the United States used 140 billion gallons of gasoline [2], so there is the potential to economically supply all of the current gasoline needs with wind-generated hydrogen. 


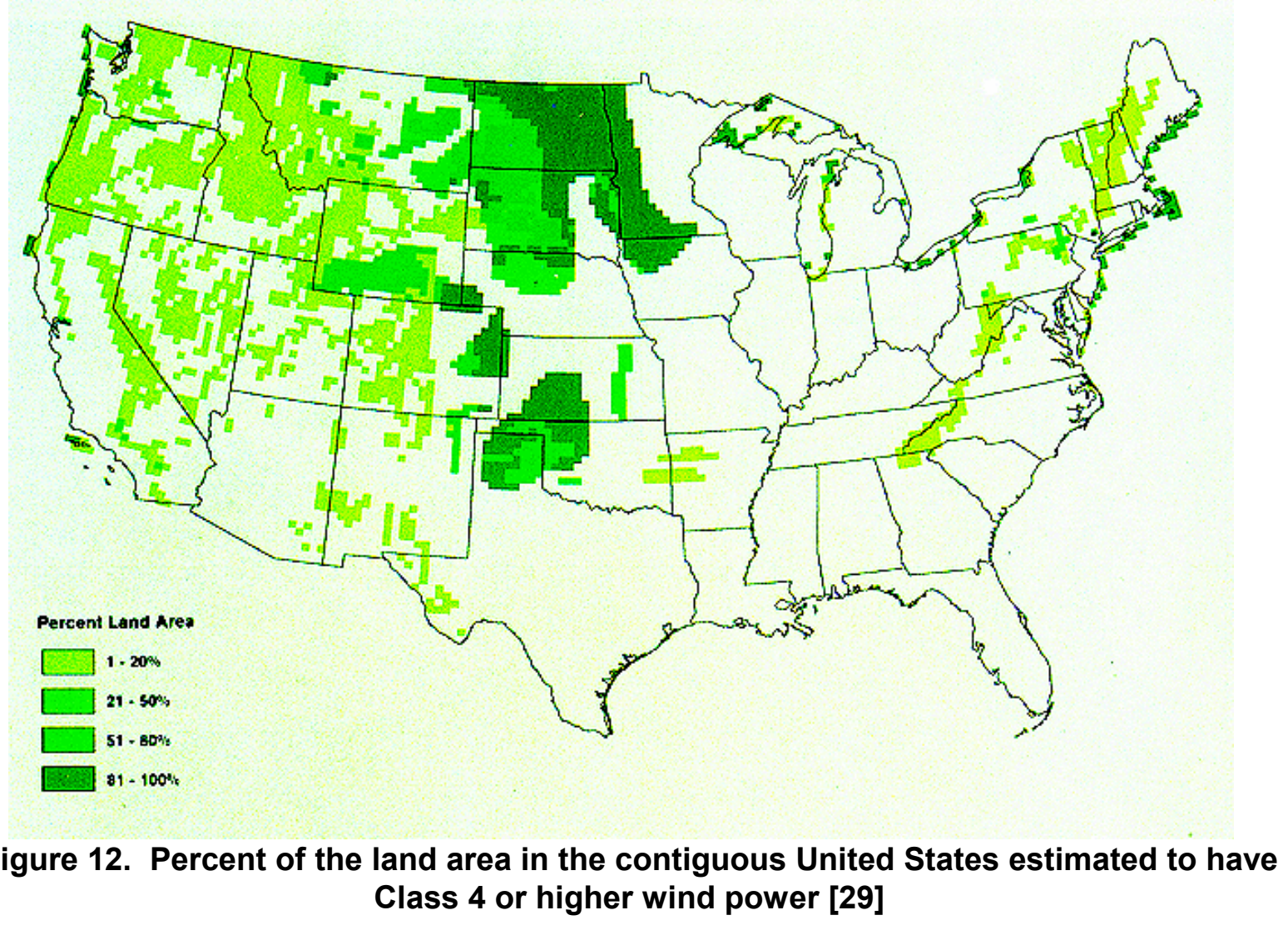

The class of wind is important because it determines the capacity factor of the wind. Both the capacity factor and the price of electricity from the wind farm are critical parameters in the economics of hydrogen produced from wind. An analysis was conducted to quantify the effects of these two parameters on hydrogen delivered from central wind production plants.

Figure 13 shows how delivered hydrogen price changes with different capacity factors and electricity prices for currently available (2005) electrolyzer technologies. In the current case the wind farm does not have the capability of coproducing electricity or purchasing electricity from the grid so the electrolyzer farm is sized to the maximum capacity of the wind farm, and operates with a capacity factor of $30 \%, 41 \%$, or $55 \%$. The COE at which the wind farm produces power was then varied for each capacity factor to determine the effects of electricity prices and capacity factors. Higher electricity prices represent higher wind farm costs; lower electricity prices represent lower wind farm costs. Higher capacity factors represent more efficient or higher class wind farms; lower capacity factors represent less efficient or lower class wind farms. 


\section{Current Centralized Wind Hydrogen Cost Dependencies on Electricity \\ Price for Various Electrolysis Capacity Factors \\ Assumes: $\$ 800 / \mathrm{kW}$ electrolyzer installed, $53.4 \mathrm{kWh} / \mathrm{kg}$ of hydrogen by electrolyzer $(64 \% \mathrm{LHV}$ efficiency), 10\% IRR, \$3.50/GGE delivery cost}

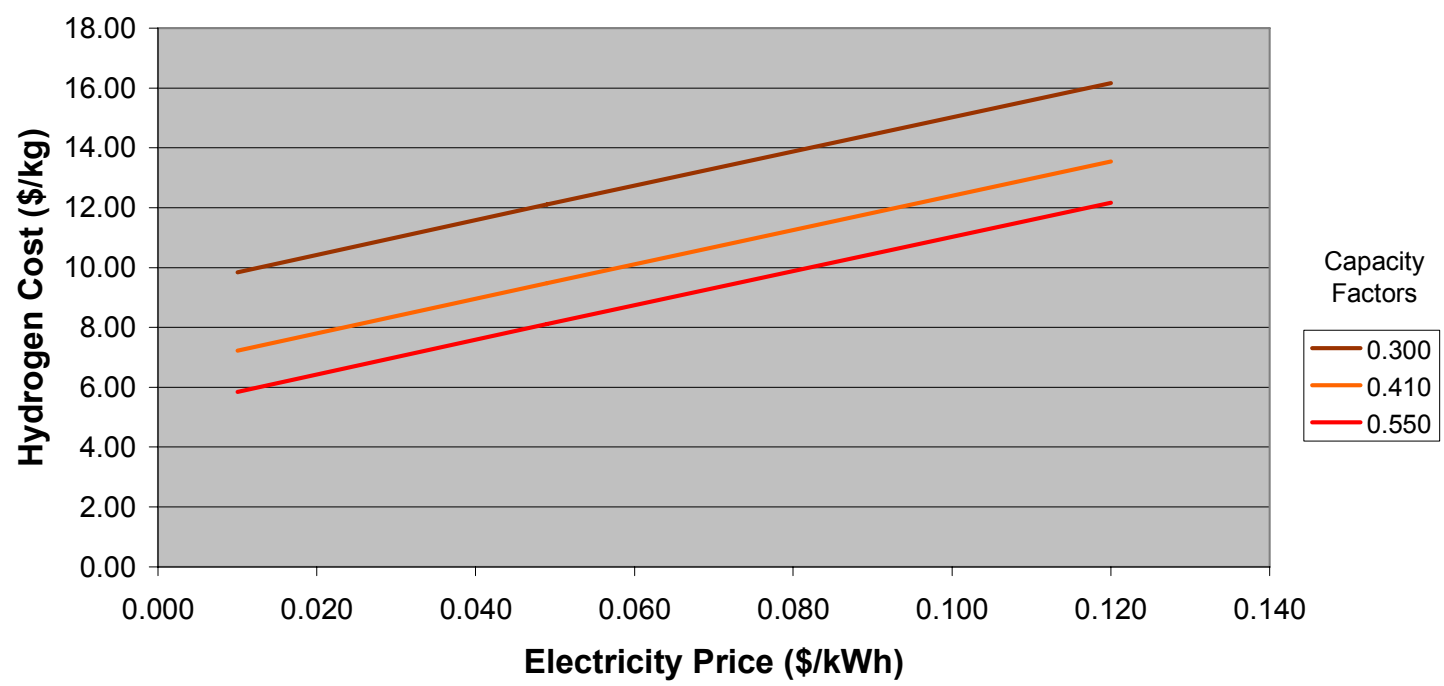

Source: Cost, resource requirements, energy requirements, all fuel and feedstock energy contents, and efficiency values for the Current (2005) case is from the National Renewable Energy Laboratory and the H2A model, Version 1.0.9 for a $125,000 \mathrm{~kg} /$ day capacity wind electrolysis facility.

\section{Figure 13. Current (2005) wind hydrogen production system: capacity factor and} electricity price effects on hydrogen cost in $\$ / \mathrm{kg}$

As we look at a future case, we make assumptions based on best available plans from industry. Figure 14 shows how hydrogen cost changes at different capacity factors and electricity prices for a future case where electrolyzer costs have decreased, electrolyzer efficiencies have increased, and delivery costs have decreased. The higher capacity factor cases here allow for wind farms that have the possibility of buying electricity from the grid so that the electrolyzer can operate at its maximum operating capacity factor of $97 \%$. The capacity factors and electricity prices were then varied to determine the effects of these parameters on hydrogen produced from the system. Higher electricity prices represent either higher wind costs, higher grid electricity costs, or a combination of the two. Every lowering of the capacity factor can either represent a system with less wind available, or a system with less grid electricity available at the specified electricity price.

In the current case, capacity factor and electricity price increases lead to larger increases in hydrogen price when compared to the future case. The capacity factor has a larger effect in the current case because of the higher capital cost of the system. It costs more to have the current systems idle than the future systems. The electricity price has a larger effect in the current systems because the systems are less efficient. In the current systems $53.4 \mathrm{kWh}$ are required to produce 1 kilogram of hydrogen; in the future systems, only $44.5 \mathrm{kWh}$ are needed to produce 1 kilogram of hydrogen. A higher $\mathrm{COE}$ leads to a higher hydrogen price in the current system because more electricity is needed to produce each kilogram of hydrogen. This simple analysis shows the importance of maximizing the capacity factors of wind 
hydrogen systems and minimizing the electricity costs from the wind, or a combined wind/grid system.

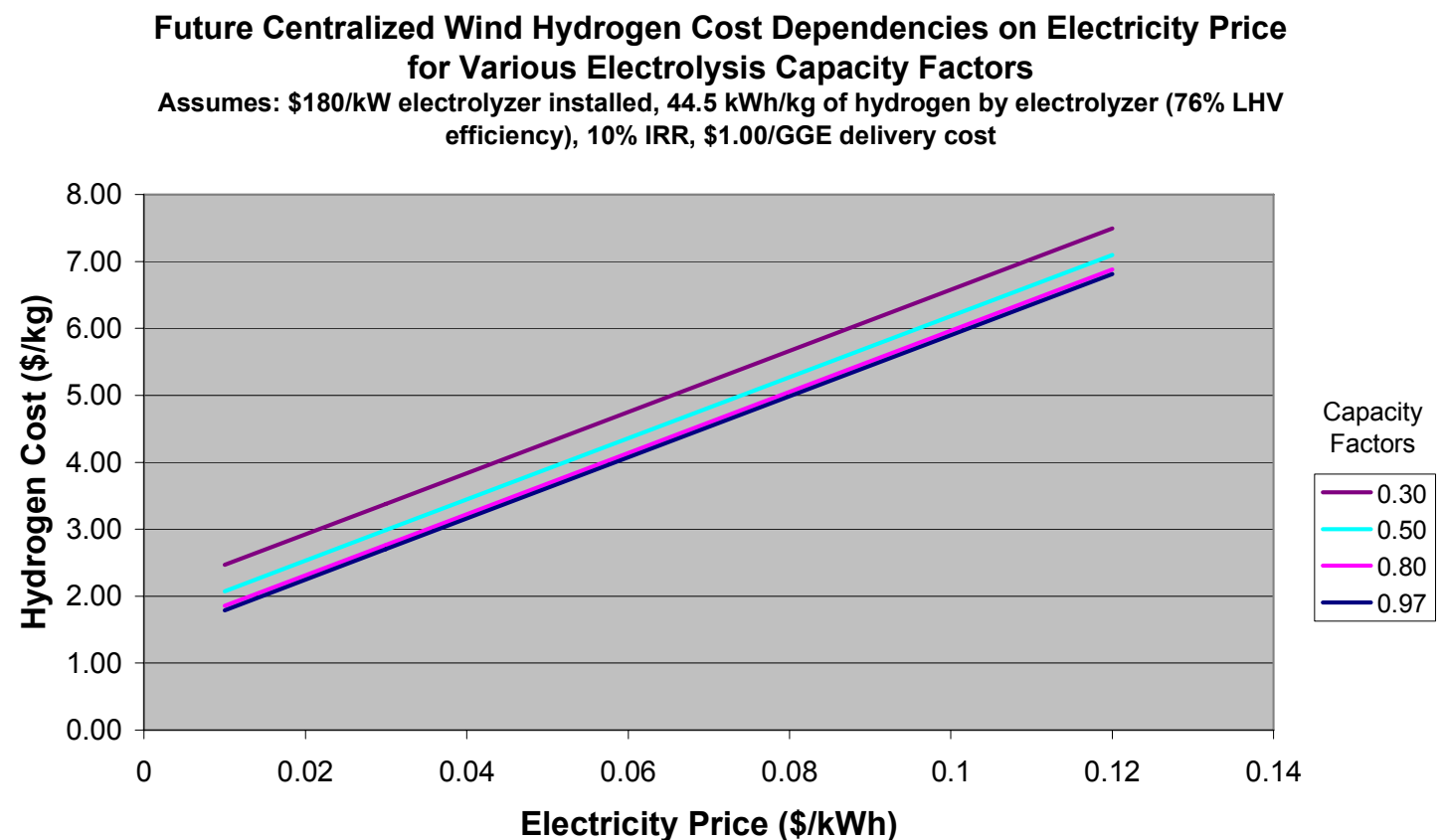

Source: Cost, resource requirements, energy requirements, all fuel and feedstock energy contents, and efficiency values for the Future (2030) case is from the H2A model cases modified to reflect the Department of Energy's Hydrogen Fuel Cells, and Infrastructure Technologies Program 2015 cost goals as of November 2005.

\section{Figure 14. Future wind hydrogen production system: capacity factor and electricity price effects on hydrogen cost in $\$ / \mathbf{k g}$}

Another important aspect of the eventual cost of hydrogen is whether it is produced centrally and delivered or produced in a distributed fashion at the point of use (Figure 15). Recent studies have shown that in the future, hydrogen produced from wind - either at the wind farm or at the point of use - has the potential to meet the DOE cost goals of $\$ 2.00-\$ 3.00 / \mathrm{kg}$, including production, delivery, and dispensing. If electricity from several wind farms is available at the filling station for $\$ 0.038 / \mathrm{kWh}$, distributed hydrogen production can meet the cost goal. Hydrogen production at the wind site makes fiscal sense if the wind/hydrogen system can be optimized in such a way that cost reductions of the combined system offset delivery cost. The central and distributed systems will require increases in electrolyzer efficiencies and decreased capital costs from today's numbers [35]. 


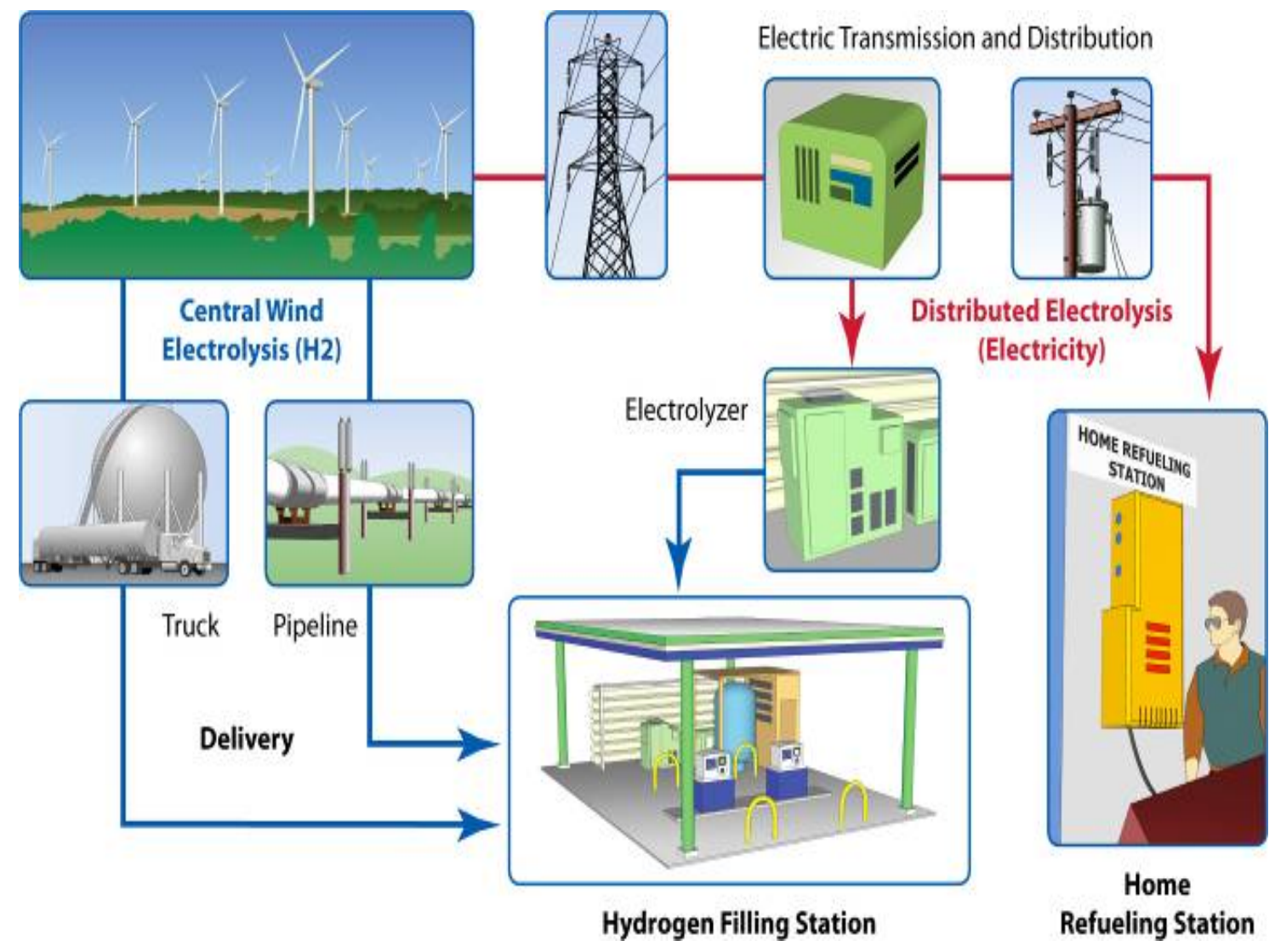

Figure 15. Examples of wind electrolysis being produced centrally or distributed at the point of use 


\section{Opportunities for Electrolysis}

There are several potential benefits of using electrolysis as an integral part of operations in the electric power industry. If just the transportation market switched to a hydrogen-based product, this could be a large new opportunity for electric utilities to provide electricity for electrolysis or possibly provide the hydrogen end product.

In 2004, the United States used 140 billion gallons of gasoline. This would be equivalent to approximately the same number of kilograms of hydrogen if it were combusted in a hydrogen ICE. Hydrogen produced via electrolysis would require 8,090 TWh of electricity based on an electrolyzer system efficiency of $67 \%$. This would require a doubling of the current throughput of the electrical power system. The current electrical system installed capacity is $938 \mathrm{GW}$ and runs at an overall capacity factor of $45 \%$ [2]. If electrolyzers were used only during off-peak times, this would increase the efficiency of the electrical power system by allowing it to run closer to its rated capacity.

If off-peak electricity is inexpensive compared to on-peak, energy storage can be a valuable resource. Producing and storing hydrogen during off-peak times can add load to the off-peak times and create stores of energy to be used in conjunction with a fuel cell or hydrogen engine-generator set to produce electricity when it is needed most. Several studies about using off-peak hydrogen production have been conducted [36, 37].

The benefits of using off-peak electricity to make hydrogen include improving the load factor of electric power distribution and transmission facilities and increasing the efficiencies of intermediate generation by allowing them to run at their optimal efficiencies. One of the biggest drawbacks to using hydrogen is the round-trip efficiency. Since current technology electrolyzers, fuel cells, and engines have relatively low efficiencies, the total hydrogen production-storage-use system will have low round-trip efficiencies.

Another benefit of electrolysis is that it can reduce the intermittent electricity production from renewable resources. By making hydrogen and storing it for later use, hydrogen systems can improve the capacity factor of renewable energy systems. This could help to make the output of the renewable energy constant, or it could be used for peaking periods only. This would also allow for transmission-constrained areas to store hydrogen off peak and use it for grid support on peak. By allowing for coproduction of hydrogen and electricity, the utility could optimize its production and storage, and optimize the system based on economics or reliability factors.

Hydrogen production would also be used to capture "stranded" wind resources where new transmission cannot be built. Wind hydrogen production systems may also benefit from being able to coproduce electricity along with the hydrogen. Analyses have shown that systems that are optimized for hydrogen production and electricity generation have slightly lower hydrogen prices, even if the electricity is sold at prices as low as $\$ 0.03 / \mathrm{kWh}$ [38]. 
There are also ways to reduce the cost of renewable-electrolysis systems. The power electronics of the renewable energy system and electrolyzer [39, 40] might be integrated, and wind towers might be used as hydrogen storage tanks [41].

A near-term application for electric utilities is the use of electrolysis to produce hydrogen on site for generator cooling. Here hydrogen gas, with its high thermal capacity and low density, is used as a cooling agent [5]. Electric utilities benefit because they can generate pure and pressurized hydrogen on site via electrolysis using inexpensive electricity from their power plant. This is often the least expensive option compared with purchasing and storing bottled hydrogen that has been produced elsewhere for the same purpose [42]. Another potential market for electrolytically produced hydrogen is ammonia production for fertilizer use. In this application, hydrogen would need to be produced at lower costs than SMR to be economical. The near- and long-term uses for hydrogen would be for transportation fuels. There is potential for all U.S. transportation needs to be met with hydrogen that is produced from clean energy sources. 


\section{Future Directions}

In October 2005 the utility industry, with the help of DOE, the National Renewable Energy Laboratory (NREL), the Electric Power Research Institute (EPRI), and the National Hydrogen Association (NHA), formed the Hydrogen Utility Group (HUG). Its mission is to accelerate utility integration of promising hydrogen energy-related business applications through the coordinated efforts and actions of its members in collaboration with key stakeholders, including government agencies and utility support organizations. The utilities that founded HUG are Arizona Public Service, DTE Energy, Entergy, Fort Collins Utilities, Nebraska Public Power District, New York Power Authority, Sacramento Municipal Utility District, Southern Company, and Xcel Energy.

Several projects that examine renewable electrolysis are underway. The City of Fort Collins, Colorado, along with support from the Governor's Office of Energy Management will soon have hydrogen and Hythane ${ }^{\circledR}$ (a mixture of hydrogen and natural gas) fueling capability to go along with the compressed natural gas $(\mathrm{CNG})$ fueling station [43]. The alkaline electrolyzer used in the project is unique in that it will produce hydrogen at 6,500 psig without a compressor. Cascade storage will allow 5,000 psig vehicle fueling. The dispenser can fuel hydrogen and Hythane vehicles. Vehicles designed to run on CNG can be fueled with Hythane, which will result in a $40 \%-50 \%$ reduction in emissions compared to CNG.

DOE awarded Basin Electric Power Cooperative a contract to investigate a wind-to-hydrogen system [44]. The project will install an alkaline electrolyzer that can produce $30 \mathrm{Nm}^{3} / \mathrm{h}$ of hydrogen gas running in one of four dynamically scheduled power delivery modes. Dynamically scheduled wind power will be dispatched to the grid-connected electrolyzer in Minot, North Dakota, based on an output signal from one of North Dakota's geographically diverse wind facilities [40]. The University of North Dakota's Energy \& Environmental Research Center conducted a feasibility study and determined that hydrogen will be produced for $\$ 10-\$ 20 / \mathrm{kg}$.

The University of Minnesota West Central Research and Outreach Center is developing a wind-to-hydrogen demonstration system in partnership with Xcel Energy and other Minnesota stakeholders [45]. Installation of the 1.65-MW wind turbine was completed in March 2005 with funding from the Legislative Commission on Minnesota Resources.

Completion of the first phase of the three-phase project will include the installation of a 400$\mathrm{kW}$ alkaline electrolyzer, hydrogen storage tanks, ICE generator, and interconnection to the grid. Primary project goals involve the use of wind-derived hydrogen gas to produce transportation fuels and agricultural products and mixing with natural gas for utility peakshaving.

NREL and Xcel Energy are working on a project to analyze and compare hydrogen production from wind power and the electric grid. The hydrogen will be produced through electrolysis, compressed, stored, and used to run an engine during peak electrical demand periods. The project will explore creating synergies from coproduction of electricity and 
hydrogen to address the intermittent nature of wind power, creating a ready source of electricity for when the wind doesn't blow or the demand for electricity is high, consistent support of the electric grid from off-peak storage of hydrogen, and the potential use of hydrogen for vehicle use. Research will include comparing multiple electrolyzer technologies, including an alkaline electrolyzer and PEMs to gauge their efficiencies; their abilities to be brought on- and off-line quickly; and the development of AC-DC and DC-DC converters to direct couple the wind turbine to the electrolyzer to achieve efficiency gains. Figure 16 shows a planned layout for the project.

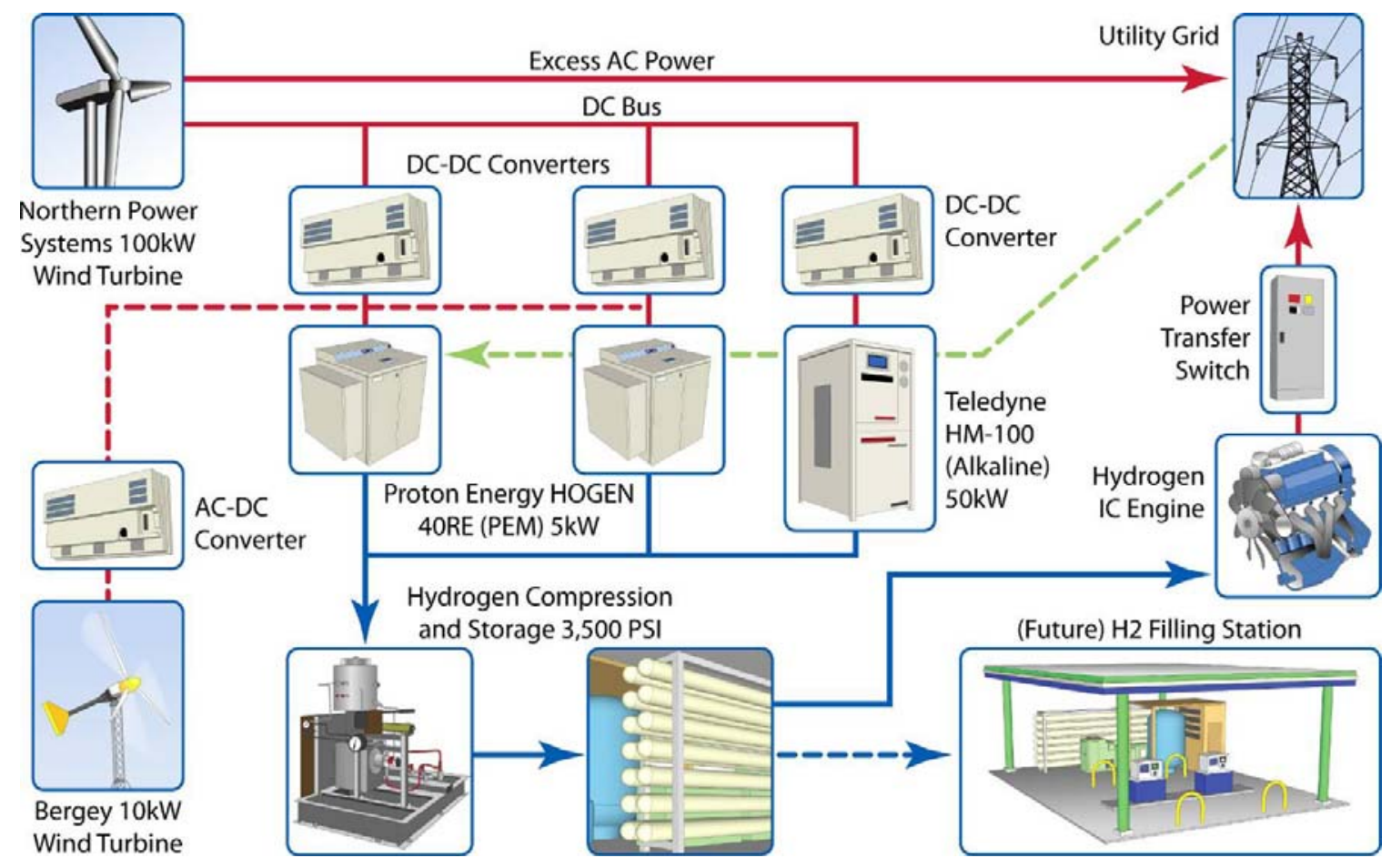

Figure 16. Xcel-NREL Wind2H2 project diagram 


\section{Conclusions}

This report describes the opportunities for the electric power industry as our fossil-fuel economy shifts to using hydrogen. The electric power industry is in a unique position, if the transportation sector converts to hydrogen produced from clean energy sources, to help the country increase energy independence and reduce carbon and pollution levels. The current transportation market is larger than the current electricity market. If electrolysis is used to produce hydrogen, utilities could more than double the amount of electricity they provide, and some could be provided without adding capacity. There are more than enough solar and wind resources in the United States to produce all the hydrogen needed from wind and solar resources, so utilities could provide a clean, carbon-free fuel. In addition, there are market opportunities today for utilities to start gaining experience in hydrogen production, if they wish to position themselves as transportation fuel providers of the future.

Electrolysis can only meet the DOE cost target of $\$ 2.00-\$ 3.00 / \mathrm{kg}$ for hydrogen if inexpensive electricity is available. However, studies have shown that electrolysis is a costeffective way to produce hydrogen from clean energy sources, including renewables like solar and wind. Several utilities are currently conducting research into the integration and optimization of these technologies into the electric power system. 


\section{References}

[1] B. Suresh, S. Schlag, and Y. Inogucji, "Chemical Economics Handbook Marketing Research Report," SRI Consulting, 2004.

[2] EIA, “Annual Energy Review 2004,” Report No. DOE/EIA-0384 (2004), August 2005, www.eia.doe.gov/emeu/aer/pdf/aer.pdf.

[3] D. Gregory, "A Brief History of the Hydrogen Energy Movement," Symposium Papers: Hydrogen for Energy Distribution, Institute of Gas Technology, Chicago, 1978.

[4] J. Verne, The Mysterious Island (1874) - A New Translation: translated by Jordan Stump, Modern Library, 2001.

[5] D. Gregory, “A Hydrogen-Energy System," Report for American Gas Association, Cat. No. L21173, August 1972.

[6] D. Gregory, "The Hydrogen Economy," in Scientific American, vol. 228, No. 1, 1973, pp. 13-21.

[7] L. Lessing, "The Coming Hydrogen Economy," in Fortune, vol. 86, No. 5, 138, 1972.

[8] M. Lotker, "Hydrogen for the Electric Utilities - Long Range Possibilities," presented at 9th Intersociety Energy Conversion Engineering Conference, 1974.

[9] N. Lymberopoulos, "Hydrogen Production from Renewables," Center for Renewable Energy Sources (C.R.E.S), Pikermi Attiki, Project Technical Assistant Framework Contract EESD Contract No: NNE5-PTA-2002-003/1, September 2005.

[10] K. E. Cox and J. K. D. Wiliamson, "Hydrogen: Its Technology and Implications," Production Technology, CRC Press, vol. 1, 1977.

[11] A. Konopka and D. Gregory, "Hydrogen Production by Electrolysis: Present and Future," presented at 10th Intersociety Energy Conversion Engineering Conference, IEEE Cat. No. 75CHO 983-7 TAB, 1975.

[12] D. H. Smith, "Industrial Water Electrolysis," in Industrial Electrochemical Processes, A. T. Kuhn, Ed.: Elsevier Publishing Company, 1971, pp. 127-157.

[13] “Technology Brief: Analysis of Current-Day Commercial Electrolyzers," NREL, Golden, CO NREL/FS-560-36705, September 2004.

[14] W. Kincaide, "Alkaline Electrolysis: Past, Present and Future," presented at Hydrogen for Energy Distribution, Institute of Gas Technology, 1978.

[15] "Ryton ${ }^{\circledR}$ PPS - Chevron Phillips Chemical Company LLC. Retrieved on June 29, 2006 from www.cpchem.com/enu/ryton_pps.asp, 2006.

[16] E. Chapman, "Production of Hydrogen by Electrolysis," Chemical Process Engineering, vol. 44, pp. 387-393, 1965.

[17] J. B. S. Haldane, "DAEDALUS or Science and the Future." Cambridge, 1923.

[18] P. Hoffman, "Tomorrow's Energy - Hydrogen, Fuel Cells, and the Prospects for a Cleaner Planet," The MIT Press, 2001.

[19] J. Bockris, Energy The Solar-Hydrogen Alternative. New York: John Wiley \& Sons, 1975.

[20] K. Cox, "Hydrogen from Solar Energy via Water Electrolysis," presented at 11th Intersociety Energy Conversion Engineering Conference, IEEE Cat. No. 75CHO 9837 TAB, 1976. 
[21] J. Hanson, "Concepts for Solar Production of Hydrogen,” Hydrogen for Energy Distribution, Institute of Gas Technology, July 1978.

[22] R. Foster, R. Tison, and W. Escher, "Solar/Hydrogen Systems for the 1985-2000 Time Frame," Final Report Jet Propulsion Laboratory, June 1980.

[23] W. Grasse and F. Oster, "HYSOLAR Solar Hydrogen Energy Results and Achievements 1985-1989." University of Stuttgart, Germany, 1990.

[24] E. Ben-Dov, P.S. Rudman, and Y. Naot, "Hydrogen Fuel Production by Wind Energy Conversion,” Alternative Energy Sources, Vol. 8 Hydrogen Energy, pp.3563-3569, 1978.

[25] M. Dubey, "Hydrogen From Wind - A Clean Energy System," Alternative Energy Sources, Vol. 8 Hydrogen Energy, pp.3551-3561, 1978.

[26] H. De Battista, R. Mantz, F. Garelli "Power conditioning for a wind-hydrogen energy system", Journal of Power Sources, Vol. 155, pp.478-486, 2005.

[27] S. Kelouwani, K. Agbossou, and R. Chahine, "Model for energy conversion in renewable energy system with hydrogen storage", Journal of Power Sources, Vol. 140, pp.392-399, 2004.

[28] S. Sherif, F. Barbir, and T. Veziroglu, "Wind energy and the hydrogen economy review of the technology", Solar Energy, Vol 78, pp.647-660, 2005.

[29] J. I. Levene, M. K. Mann, R. Margolis, and A. Milbrant, "Analysis of Hydrogen Production from Renewable Electricity Sources," NREL, Golden, CO Report No. CP560-39702, 2005.

[30] “DOE Hydrogen Program: DOE H2A Analysis," Retrieved on June 29, 2006 from www.hydrogen.energy.gov/h2a_analysis.html.

[31] "Hydrogen Cost Targets." Retrieved on June 22, 2006 from www.hydrogen. energy.gov/news_cost_goal.html, 2005.

[32] "DOE Solar Energy Technologies Program Overview and Highlights," NREL, Golden, CO BR-520-29081; DOE/GO-102006-2314, 2006.

[33] "Wind Energy Multi Year Program Plan for Year 2005-2010," NREL Wind and Hydro Power Technologies Program, November 2004, www.nrel.gov/wind_meetings/ 2003_imp_meeting/pdfs/wind_prog_mypp_15Nov2004.pdf.

[34] D. L. Elliott, C. G. Holladay, W. R. Barchet, H. P. Foote, and W. F. Sandusky, "Wind Energy Resource Atlas of the United States," Pacific Northwest Laboratory, Richland, WA DOE/CH 10093-4, October 1986, http://rredc.nrel.gov/wind/pubs/ atlas/titlepg.html.

[35] J. Levene, B. Kroposki, and G. Sverdrup, "Wind Energy and Production of Hydrogen and Electricity - Opportunities for Renewable Hydrogen," NREL Report No. CP-56039534, 2006.

[36] J. Burger and P. Lewis, "Energy Storage for Utilities via Hydrogen Systems," presented at 9th Intersociety Energy Conversion Engineering Conference, 1974.

[37] R. Fernandes, "Hydrogen Cycle Peak-Shaving for Electric Utilities," presented at 9th Intersociety Energy Conversion Engineering Conference, 1974.

[38] J. I. Levene, “An Economic Analysis of Hydrogen Production from Wind," NREL, Golden, CO NREL/CP-560-38210, May 2005. 
[39] C. Elam, B. Kroposki, G. Bianchi, and K. Harrison, "Renewable electrolysis integrated system development and testing," NREL, Golden, CO, DOE Hydrogen Program, Progress Report FY2004, 2004.

[40] L. J. Fingersh, "Optimized Hydrogen and Electricity Generation from Wind," NREL, Golden, CO NREL/TP-500-34364, June 2003.

[41] R. Kottenstette and J. Cotrell, "Hydrogen storage in wind turbine towers," NREL, Golden, CO, www.nrel.gov/docs/fy03osti/34656.pdf, September 2003.

[42] D. J. Smith, "Advances in Power Plant Generator Cooling, Driving Plant Performance," in Power Engineering, www.protonenergy.com/data/Unsorted/ PwrEngr_Gen_Cooling-09-02-17244.pdf, 2002.

[43] G. Schroeder, "Transition to the Hydrogen Age Transition to the Hydrogen Age: Myths and Realities.” Retrieved on June 29, 2006 from http://fcgov.com/utilities/pdf/ eps06-fuel-hydrogen.pdf, 2006.

[44] D. D. Schmidt, C. A. Wocken, K. M. Leroux, B. G. Stevens, K. D. Williams, and R. R. Hill, "Wind-to-Hydrogen Feasibility Study," University of North Dakota, Energy \& Environmental Research Center, Grand Forks, Final Report 2005-EERC-08-06, August 2005.

[45] "Hybrid Wind Energy System." Retrieved on June 26, 2006, from http://energy. coafes.umn.edu/windenergy: University of Minnesota, Research and Demonstration Center, 2005. 


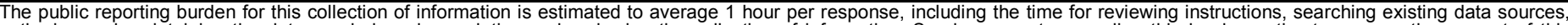

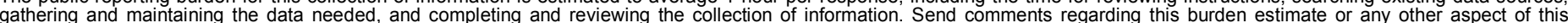

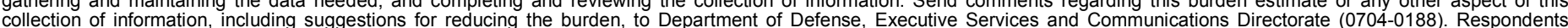

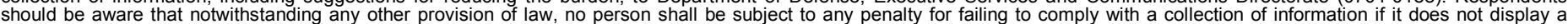

should be aware that notwithstanding

PLEASE DO NOT RETURN YOUR FORM TO THE ABOVE ORGANIZATION.

\begin{tabular}{l|l|l|l} 
1. REPORT DATE $(D D-M M-Y Y Y Y)$ & 2. & REPORT TYPE & 3. DATES COVERED (FrOm - TO)
\end{tabular}

September 2006

Technical Report

4. TITLE AND SUBTITLE

Electrolysis: Information and Opportunities for Electric Power

Utilities

5a. CONTRACT NUMBER

DE-AC36-99-G010337

5b. GRANT NUMBER

5c. PROGRAM ELEMENT NUMBER

6. AUTHOR(S)

B. Kroposki, J. Levene, K. Harrison, P.K. Sen, and F. Novachek

5d. PROJECT NUMBER

NREL/TP-581-40605

5e. TASK NUMBER

HY613620

5f. WORK UNIT NUMBER
7. PERFORMING ORGANIZATION NAME(S) AND ADDRESS(ES)

National Renewable Energy Laboratory

1617 Cole Blvd.

Golden, CO 80401-3393

9. SPONSORING/MONITORING AGENCY NAME(S) AND ADDRESS(ES)
8. PERFORMING ORGANIZATION REPORT NUMBER

NREL/TP-581-40605
10. SPONSOR/MONITOR'S ACRONYM(S) NREL

11. SPONSORING/MONITORING AGENCY REPORT NUMBER

12. DISTRIBUTION AVAILABILITY STATEMENT

National Technical Information Service

U.S. Department of Commerce

5285 Port Royal Road

Springfield, VA 22161

13. SUPPLEMENTARY NOTES

14. ABSTRACT (Maximum 200 Words)

Recent advancements in hydrogen technologies and renewable energy applications show promise for economical near- to mid-term conversion to a hydrogen-based economy. As the use of hydrogen for the electric utility and transportation sectors of the U.S. economy unfolds, electric power utilities need to understand the potential benefits and impacts. This report provides a historical perspective of hydrogen, discusses the process of electrolysis for hydrogen production (especially from solar and wind technologies), and describes the opportunities for electric power utilities.

\section{SUBJECT TERMS}

hydrogen; hydrogen-based economy; electric utility; electrolysis

16. SECURITY CLASSIFICATION OF:
\begin{tabular}{|l|l|l|}
\hline $\begin{array}{l}\text { a. REPORT } \\
\text { Unclassified }\end{array}$ & $\begin{array}{c}\text { b. ABSTRACT } \\
\text { Unclassified }\end{array}$ & $\begin{array}{l}\text { c. THIS PAGE } \\
\text { Unclassified }\end{array}$ \\
\hline
\end{tabular}

\begin{tabular}{l|l|}
$\begin{array}{l}\text { 17. } \\
\text { LIMITATION }\end{array}$ & $\begin{array}{l}\text { 18. } \\
\text { NUMBER } \\
\text { OF ABSTRACT }\end{array}$ \\
UL & \\
&
\end{tabular}

19a. NAME OF RESPONSIBLE PERSON

19b. TELEPHONE NUMBER (Include area code) 